\title{
Early Eocene rodents (Mammalia) from the Subathu Formation of type area (Himachal Pradesh), NW sub-Himalaya, India: Palaeobiogeographic implications
}

\author{
Smita Gupta and Kishor Kumar* \\ Wadia Institute of Himalayan Geology, 33 General Mahadeo Singh Road, Dehradun 248 001, India. \\ *Corresponding author.e-mail: kumark@wihg.res.in
}

\begin{abstract}
Based on isolated upper cheek teeth, two new early Eocene rodents (Subathumys solanorius gen. et sp. nov. and Subathumys globulus gen. et sp. nov.) and three others (Birbalomys cf. sondaari, Birbalomys sp., cf. Chapattimys sp.) are recorded from the lower-middle part of the Subathu Formation of the type area in Himachal Pradesh, northwestern sub-Himalaya (India). The new rodents exhibit morphological features most similar to the unified ctenodactyloid family Chapattimyidae (including Yuomyidae), which is also represented in the assemblage from the upper part (middle Eocene) of the Subathu Formation. The associated lower cheek teeth are provisionally described as three indeterminate chapattimyid taxa. The new Subathu rodents are somewhat younger than the previously documented early Eocene assemblages from the Indian subcontinent, and are chronologically intermediate between the early Eocene ailuravines from Gujarat in the western peninsular India and the middle Eocene chapattimyids from northwestern India and Pakistan. They suggest that chapattimyids originated in the sub-Himalayan region during the Ypresian, which is earlier than previously believed. The absence of ailuravines in this as well as younger rodent assemblages from the subcontinent seems to suggest that ailuravines (Ischyromyidae), within a relatively short time after their appearance in the peninsular India in the early Eocene, may have been replaced by the indigenous chapattimyids. The co-occurrence in the early Eocene Subathu assemblage of three or more chapattimyids indicates their early radiation and dominance during the early and middle Eocene. This record of rodents opens the possibility of recovery of other small mammal remains in older levels of the Subathu Formation, which will be important for understanding linkage with early Eocene faunas from peninsular India, Europe and North America.
\end{abstract}

\section{Introduction}

Until about a decade ago, the Eocene terrestrial mammals in India were known only from a middle Eocene level of the late Paleocene-middle Eocene Subathu Formation in the northwestern sub-Himalaya (Ranga Rao 1971; Sahni and Khare 1973; Kumar and Sahni 1985; Kumar 1991, 1992; Kumar et al. 1997a, b). Recently, however, a variety of small and small-medium sized mammals has been documented from the early Eocene ( 54-53 Ma) Cambay Shale Formation in Vastan (Gujarat), peninsular India (Rana et al. 2004, 2008; Bajpai et al. 2005; Rose et al. 2009a, b, 2013; Kumar et al. 2010). In the Vastan mammal fauna, several taxa have closer affinities with European than with Asian relatives, suggesting a terrestrial faunal link between India and Eurasia close to the Paleocene-Eocene transition (Smith et al. 2007; Rana et al. 2008; Rose et al. 2009a, b, 2013; Kumar et al. 2010). This

Keywords. Mammalia; Rodentia; Chapattimyidae; Eocene; Subathu Formation; India.

J. Earth Syst. Sci. 124, No. 6, August 2015, pp. 1201-1221

(C) Indian Academy of Sciences 
revelation and the need to probe further the palaeobiogeographic scenarios with respect to India-Asia convergence and land mammal faunas of the critical late Paleocene-early Eocene interval prompted us to revisit the Subathu horizons in the subHimalayan region and focus on its older part. Our initial work on the early Eocene Subathu beds has yielded fossils of rodents, which bear significantly on the early radiation of Rodentia on the subcontinent, and form the basis of this contribution (figure 1).

The earliest known fossil rodents come from the late Paleocene of Asia and North America (Rose 1981; Li et al. 1987; Dawson and Beard 1996; Meng and $\mathrm{Li} 2010$ ), but the group began to diversify only in the early Eocene. In South Asia, Eocene rodents were first recorded from the middle Eocene horizons (Lutetian) - the Subathu Formation in India and the Kuldana Formation in Pakistan. From India, a diverse assemblage of Eocene rodents has been known from the uppermost part of the Subathu Formation of Himachal Pradesh as well as Jammu and Kashmir (Sahni and Khare 1973; Sahni and Srivastava 1976; Kumar et al. 1997a, b). Most of the rodents from this stratigraphic level have been referred to a rather diverse family Chapattimyidae (Ctenodactyloidea), which was then restricted in the Indo-Pakistan region, and a few to a closely similar Eastern and Central Asiatic family Yuomyidae (Kumar et al. 1997a, b). Across the border in Pakistan, a coeval terrestrial mammal yielding horizon in the Kuldana Formation of Kala Chitta Range (Punjab) yields a nearly identical assemblage of middle Eocene chapattimyids and yuomyids (Hussain et al. 1978; Hartenberger

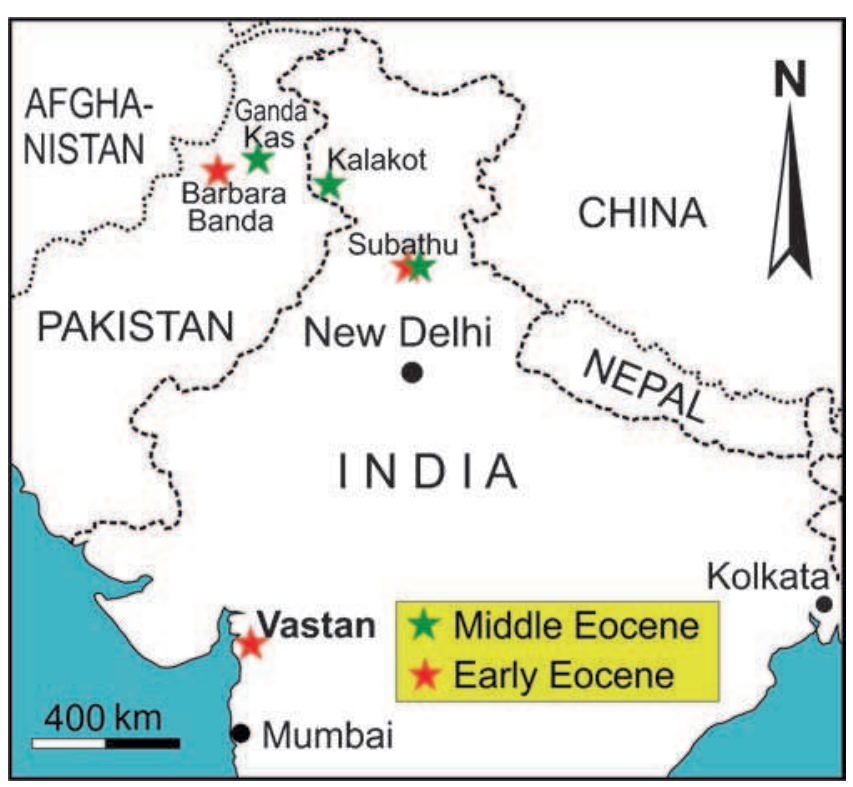

Figure 1. Map of the Indian subcontinent showing the early and middle Eocene rodent sites.
1982; Dawson et al. 1984; Thewissen et al. 2001). In contrast to fairly diverse assemblages from the middle Eocene horizons, the record of early Eocene rodents from the Indian subcontinent is rather limited both in terms of number of specimens as well as species diversity even though it is considered crucial for understanding the early radiation of Eocene rodents in the south Asian region (De Bruijn et al. 1982; Bajpai et al. 2007; Rana et al. 2008).

Herein we describe a new early Eocene rodent assemblage from a significantly older stratigraphic level in the lower-middle part of the Subathu Formation of the stratotype area in the Solan District of Himachal Pradesh - the fossiliferous level falls in Mathur and Juyal's (2000) faunal zone IV (Cordiopsis subathooensis-Turritella subathooensis zone), which is considered to be of an early Eocene (late Ypresian) age based on foraminiferal biostratigraphy. Prior to this report, early Eocene rodents in the Indian subcontinent were known only from the subsurface beds of the Cambay Shale Formation 'exposed' in the Vastan open cast lignite mine near Surat (Gujarat) in peninsular India (Bajpai et al. 2007; Rana et al. 2008) and from the Mami Khel Clay in Barbara Banda, Kohat District, northern Pakistan (De Bruijn et al. 1982).

The early Eocene rodents recorded here from Subathu represent two species of a new rodent genus Subathumys and three other taxa (Birbalomys cf. sondaari, Birbalomys sp. and cf. Chapattimys sp.), all having clear affinities with the ctenodactyloid families Chapattimyidae and Yuomyidae, which are also represented in the middle Eocene assemblage from the Subathu Formation. It may be mentioned here that both Birbalomys and Chapattimys, particularly the former, are dominant in the middle Eocene (Lutetian) assemblage from the IndoPakistan region (Hussain et al. 1978; Kumar et al. 1997a, b). The European ailuravine (Ischyromyidae) Meldimys recorded from the early Ypresian of peninsular India or any other ailuravine seems to be absent in the Subathu Formation. Similarly, cocomyids present in the early Eocene of Pakistan have not been found in the Subathu fauna so far. The record of early Eocene rodents from Subathu has multi-fold significance:

- it is the first report of rodent fossils from the early Eocene horizons of the Subathu Formation,

- the familial affinities of this assemblage are distinct from those of the previously known early Eocene rodent assemblages from India and Pakistan,

- it extends the antiquity of chapattimyids and yuomyids to the early Eocene, and

- age-wise this assemblage is intermediate, i.e., older than the one from the middle Eocene horizons (Lutetian) of the Subathu and Kuldana 
formations and younger than that from the early Eocene ( 54-53 Ma, early Ypresian) Cambay Shale Formation of peninsular India and probably also younger than that from the early Eocene Mami Khel Clay of northern Pakistan.

The new fossils have implications on palaeobiogeography and early radiation of rodents in south Asia.

\section{Geological setting}

The rodent material described in this paper was recovered from the red beds in the lower-middle part of the late Paleocene-middle Eocene Subathu Formation exposed in a tributary of the Kuthar River near the cantonment town of Subathu $\left(30^{\circ} 57^{\prime} 50^{\prime \prime} \mathrm{N} ; 76^{\circ} 58^{\prime} 33^{\prime \prime} \mathrm{E}\right)$ in the Solan District of Himachal Pradesh, northwestern India (figure 2). The Subathu Formation represents the last phase of the Tethys Sea in the northwest sub-Himalayan region and is exposed from Jammu and Kashmir in the northwest through the states of Himachal Pradesh (stratotype area) and Uttarakhand to Nepal in the southeast (Singh 1980; Nanda and Kumar 1999; Kumar and Loyal 2006). It overlies the Precambrian Simla Slates in Himachal Pradesh and Sirban Limestone in Jammu and Kashmir and is overlain by the continental deposits of the Murree Group (=Dagshai and Kasauli formations/Dharamsala Formation). It is richly fossiliferous and yields foraminifers, mollusks and fish remains, etc., almost throughout its thickness (Kumar and Loyal 1987; Kumar 1989; Mathur and Juyal 2000). The marine mammal remains occur mostly in the lower-middle part (Sahni and Kumar 1980; Sahni et al. 1980a, b; Bajpai and Gingerich 1998) and land mammals mostly in the upper part of the Subathu Formation (Ranga Rao 1971; Sahni and Khare 1973; Sahni et al. 1980a, b; Ranga Rao and Mishra 1981; Kumar and Sahni 1985; Kumar

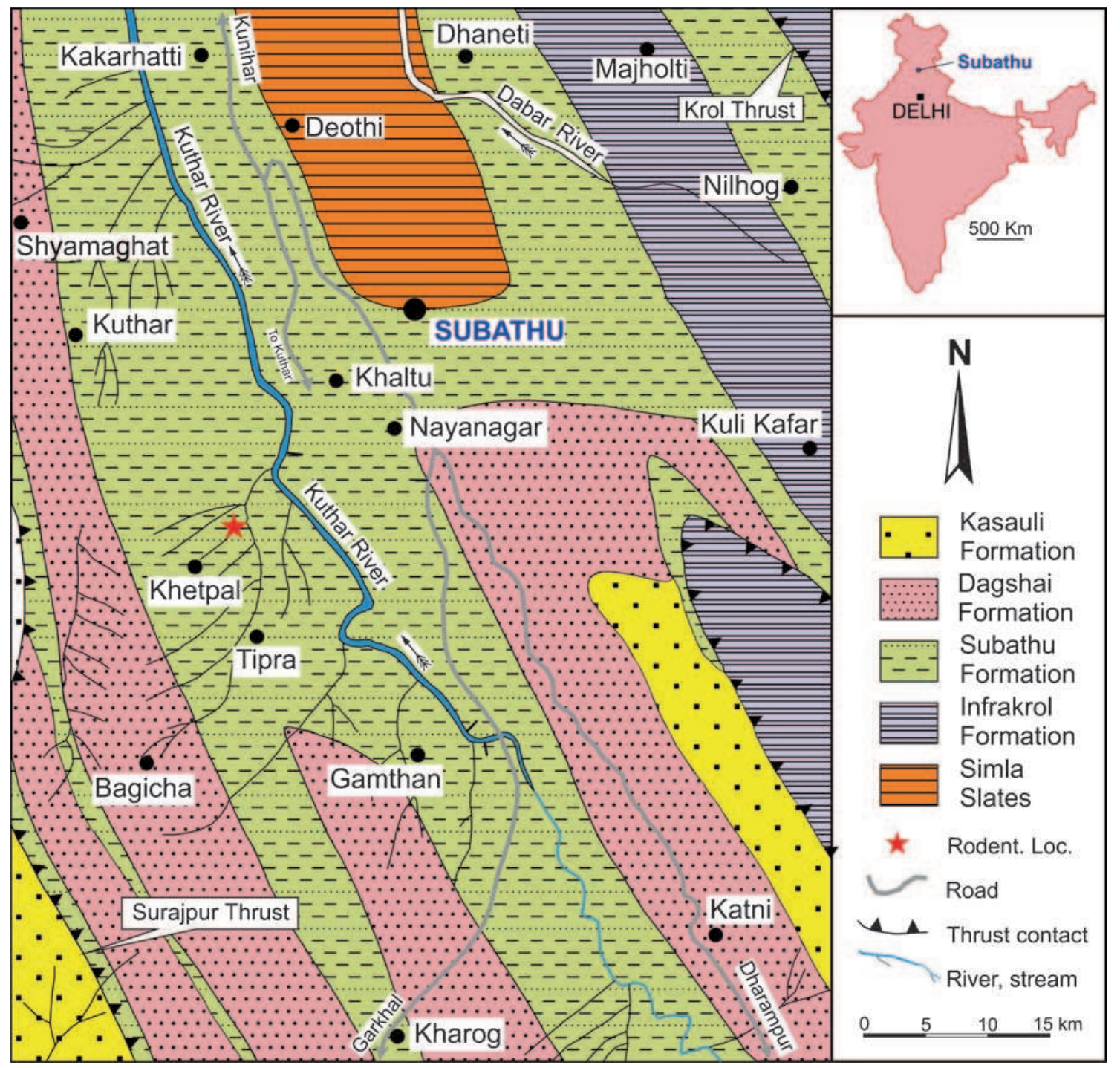

Figure 2. Geological and location map of the Subathu town in the Solan District of Himachal Pradesh showing the early Eocene rodent-yielding site; inset shows the position of Subathu in the map of India (after Kumar and Loyal 2006). 
and Jolly 1986; Kumar 1991, 1992, 2000; Srivastava and Kumar 1996; Kumar et al. 1997a, b). The land mammal remains, prior to this work, were documented only from the red beds occurring in the terminal part of the Subathu Formation, which is equivalent to Mathur and Juyal's (2000) faunal zone VIII (Musculus nuttalli-Parinomya blanfordiana zone). A generalized lithological log of the Subathu Formation showing foraminiferal zones and land mammal yielding horizons is shown in figure 3.

The Subathu Formation is largely a shallow marine grey-green shale-limestone succession with subordinate siltstone and sandstone, having continental red beds in its terminal part, which yield a variety of land vertebrates, including rodents of middle Eocene age (Kumar and Sahni 1985; Kumar et al. 1997a, b). However, in its stratotype area (Subathu, Himachal Pradesh) the red beds are also present in the lower-middle part of the Subathu Formation, indicating a short episode of sea regression (Mathur and Juyal 2000; Kumar and Loyal 2006). These red beds, here referred as the older Subathu red beds, yielded the rodents described herein. They are not present in the Subathu

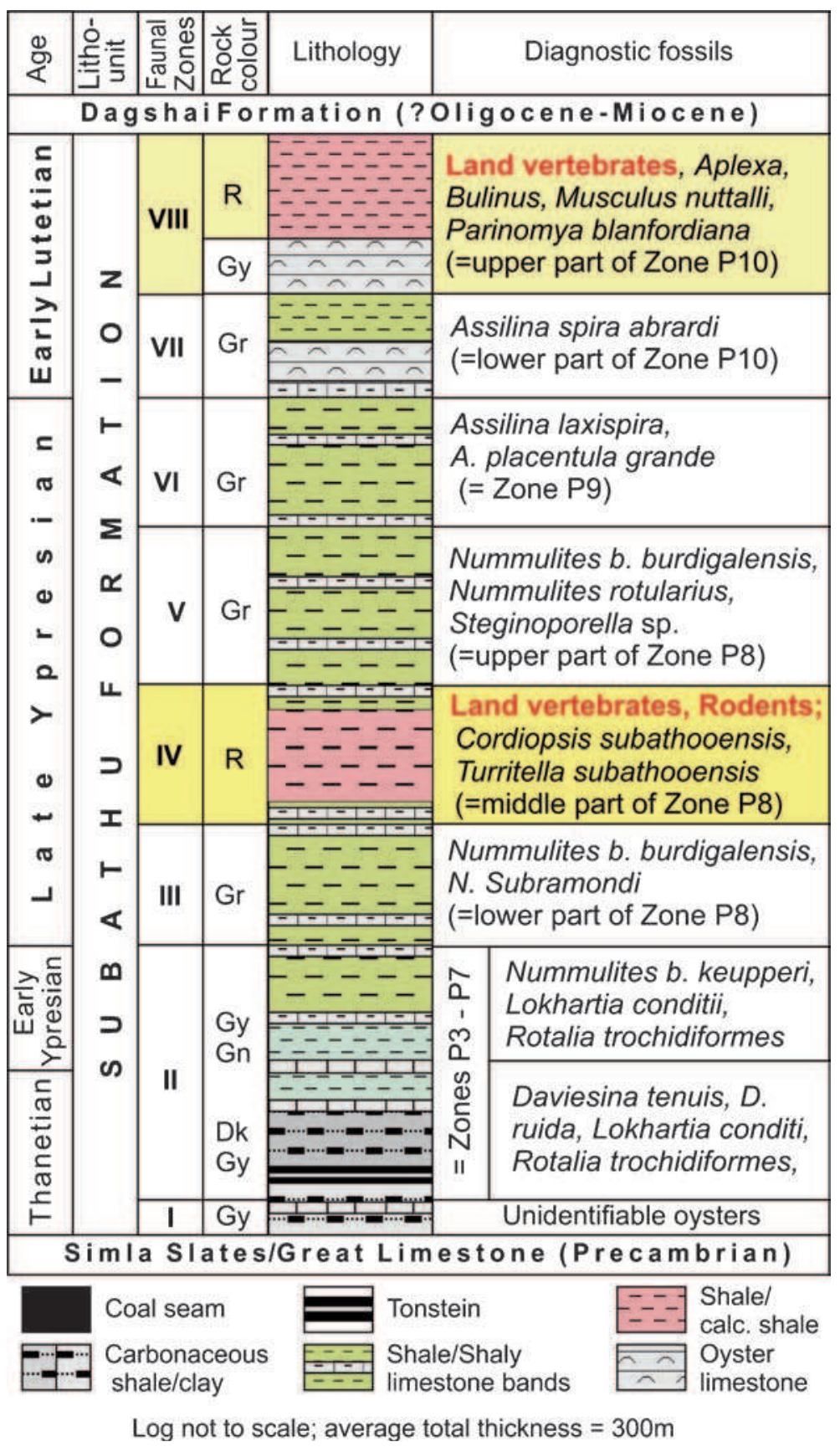

Figure 3. Generalized lithological log of the Subathu Formation showing the foraminiferal zonation (after Mathur and Juyal 2000) and the position of older and younger Subathu red beds. 
succession of other well known vertebrate rich areas, such as Kalakot, Metka and Mohgala in Jammu and Kashmir (Singh 1980; Kumar and Sahni 1985).

The older Subathu red beds comprise a $\sim 30 \mathrm{~m}$ thick zone of brownish red shales that occur as a distinct lithological unit within the shallow marine grey-green shale-limestone unit (figure 4). They correspond to Mathur and Juyal's (2000) faunal zone IV (Cordiopsis subathooensis-Turritella subathooensis zone) and are considered to be of late Ypresian age based on foraminiferal biostratigraphy. They are generally poorly fossiliferous - gastropods and rodent remains have so far been recovered from just a couple of sites along the Kuthar River that flows by the side of Subathu town. The rodent yielding fossiliferous shale is lensoidal with a maximum thickness of $\sim 20 \mathrm{~cm}$. The fossiliferous shale at times has clayey granules and is very similar to the middle Eocene rodent bearing granule stone in the terminal part of the Subathu Formation (=younger Subathu red beds). In thin sections of the fossiliferous shale, fragmentary bones and teeth and some gastropods can be seen (figure 5). The grey-green shale-limestone beds that underlie the older Subathu red beds are rich in turritellid gastropods.

\section{Materials and methods}

The new rodent material from the Subathu Formation comprises 17 isolated cheek teeth and several incisor fragments. Post-cranials, possibly of rodents

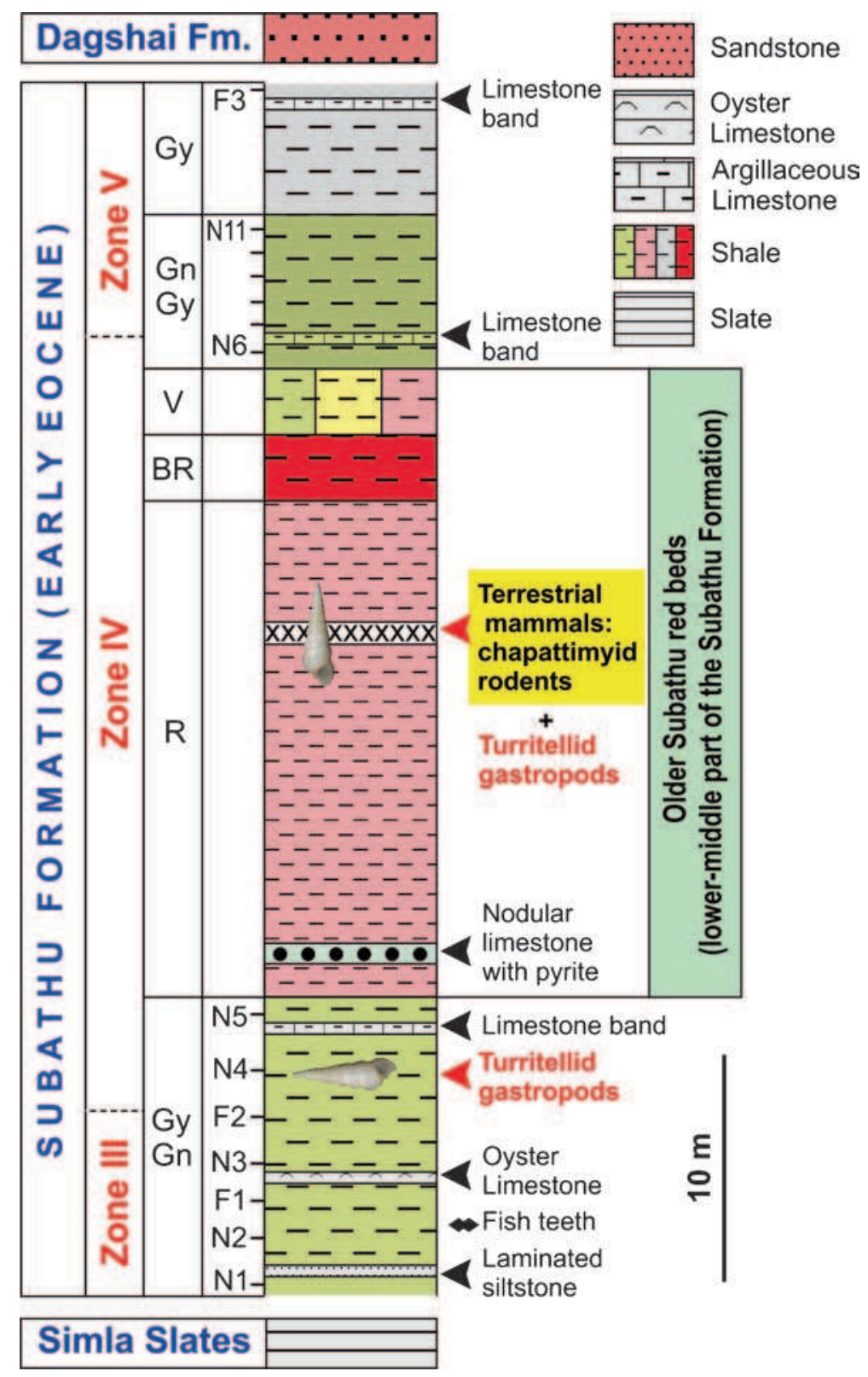

Figure 4. Lithological log of a part of the Subathu Formation showing the older Subathu red beds and the position of early Eocene rodent yielding level. 


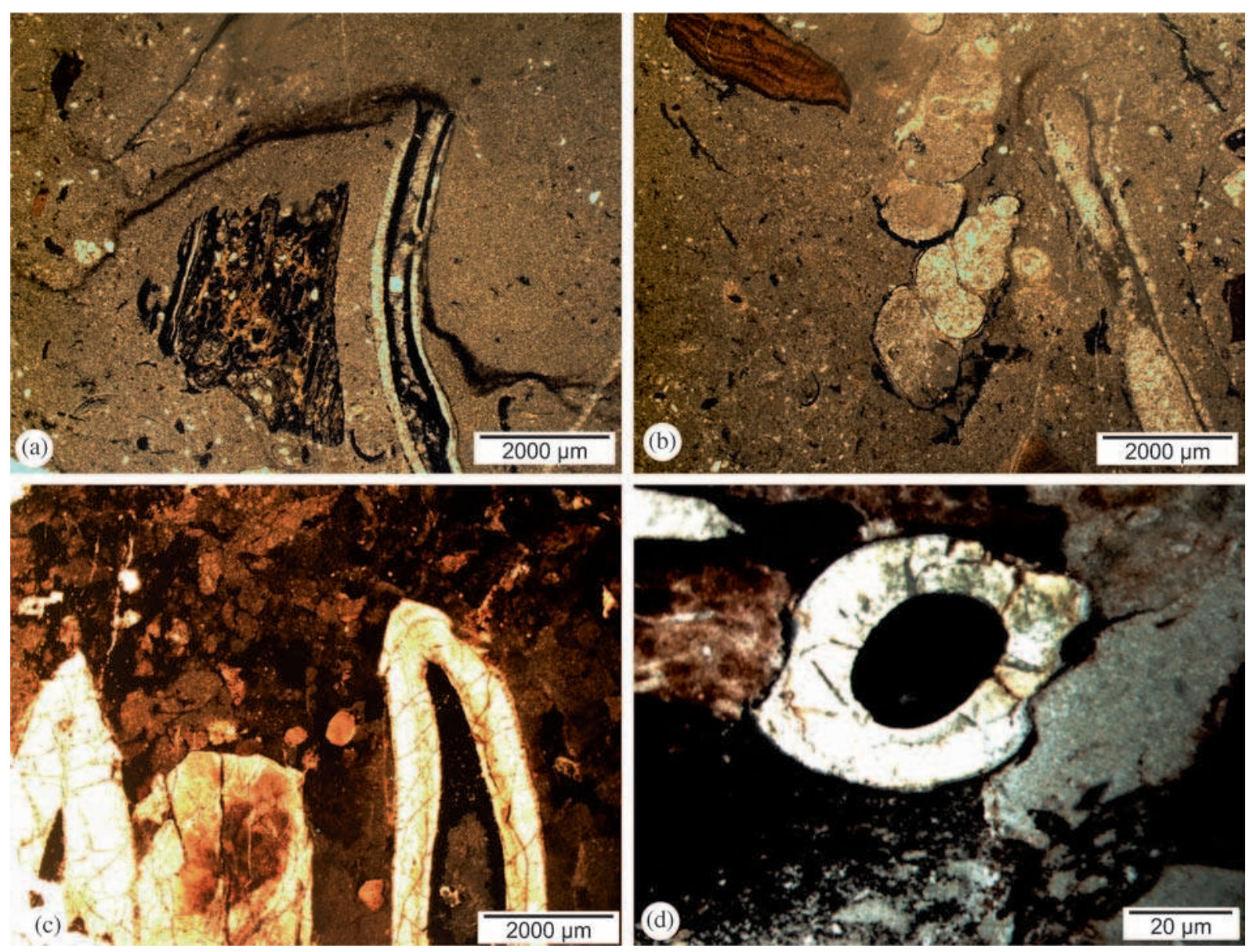

Figure 5. Photomicrographs of rodent-yielding fossiliferous sediments from the older Subathu red beds of the Subathu Formation showing bone and teeth fragments (a, c, d) and gastropods (b).

and/or other small mammals are too fragmentary and unidentifiable. Other vertebrate remains found associated with rodents include siluroid fish teeth, isolated teeth of ziphodont crocodilians, and a fragmentary tooth of an unidentified small mammal other than a rodent. Of the 17 teeth, eleven including a P3, are from the upper jaws and six from the lower. Morphologically, they exhibit clear affinities with chapattimyids and yuomyids (Ctenodactyloidea), which as already mentioned are also known from a younger level (Lutetian) of the Subathu Formation (Kumar et al. 1997a, b). Their chapattimyid-yuomyid affinity is corroborated by the two $\mathrm{P} 4 \mathrm{~s}$ in the collection, which are molariform thus precluding relationship with ctenodactylids and/or cocomyids, which have also been reported from the subcontinent (De Bruijn et al. 1982). Moreover, dominant middle Eocene chapattimyid Birbalomys is also represented in the collection. There are no lower premolars in the collection. The teeth are easily distinguishable from ailuravines (Ischyromyoidea), which have recently been documented from the peninsular India (Rana et al. 2008) by following characters: larger hypocone, smaller parastyle and mesostyle and missing crest that descends from the protocone in the talon on upper molars, and less isolated entoconid and missing or very reduced mesoconid (incorporated in the ectolophid) on lower molars (figure 6).

The upper teeth are referable to two species of a new rodent genus (Subathumys), and three other taxa closely related to middle Eocene forms. A few teeth currently described as indeterminate species may turn out to be distinct when additional material is collected and studied because in such a small collection of isolated teeth, intraspecific variations are difficult to account for. We have conscientiously refrained from attributing lower teeth to the newly erected or to other identified taxa as we found it difficult to ascertain as to which lower teeth will go with which upper and vice versa. Therefore, based on difference in size and morphology, the lower teeth are described separately under three categories, viz., Chapattimyidae indet. 1, Chapattimyidae indet. 2 and Chapattimyidae indet. 3 pending formal generic and specific assignments, when additional material is forthcoming.

All fossil materials treated herein were recovered from the same stratigraphic level and locality mostly by screen-washing of matrix using gasoline 

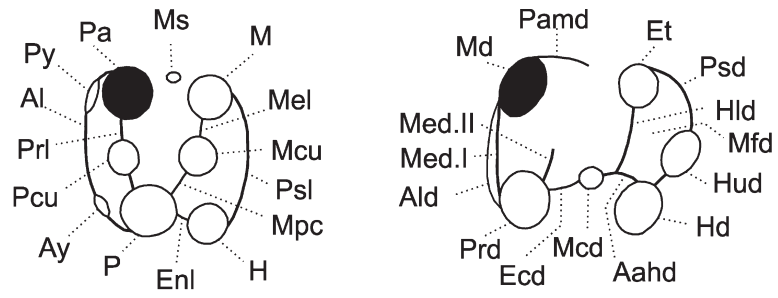

Chapattimyidae

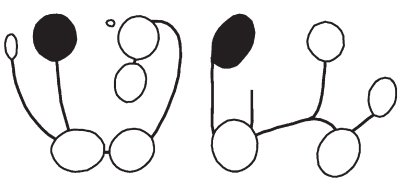

Yuomyidae

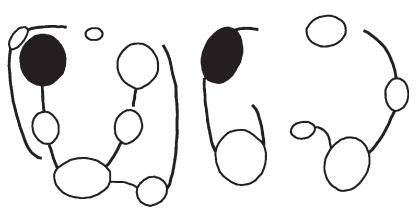

Cocomyidae

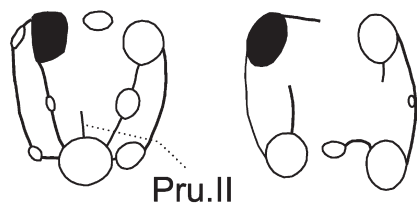

Ailuravinae

Figure 6. Schematic showing comparison of occlusal dental patterns of upper (left) and lower (right) molars for Chapattimyidae, Yuomyidae, Cocomyidae and Ailuravinae (modified after Marivaux et al. 2004). Upper molars: Al: anteroloph; Ay: anterostyle; Enl: endoloph; H: hypocone, M: metacone; Mcu: metaconule; Mel: metaloph; Mpc: metacone-protocone connection; Ms: mesostyle; P: protocone; Pa: paracone; Pcu: protoconule; Prl: protoloph; Pru.II: protolophule II; Psl: posteroloph; Py: parastyle. Lower molars: Aahd: anterior arm of hypoconid; Ald: anterolophid; Ecd: ectolophid; Et: entoconid; Hd: hypoconid; Hld: hypolophid; Hud: hypoconulid; Mcd: mesoconid; Md: metaconid; Med.I: metalophulid I; Med.II: metalophulid II (=protolophid or posterior arm of protoconid); Mfd: metafossettid; Pamd: posterior arm of metaconid; Prd: protoconid; Psd: posterolophid.

and water. A couple of teeth were extracted directly from the exposure surface. The quality of preservation of isolated teeth is variable, but generally good. We found no evidence of any post-mortem deformation, though some teeth have suffered variable amount of damage, which is ascribed to post-depositional breakage. In this paper, the upper premolars and molars are indicated by $\mathrm{P}$ and $\mathrm{M}$, respectively, and lower molars by $\mathrm{m}$. The dental terminology adopted here follows Escarguel (1999) and is depicted in figure 7. The method of measurement of teeth adopted here follows Kumar et al. (1997b) and the measurements are given in table 1 . All dimensions shown in table 1 against length and width represent maximum measured values rather than anterior/posterior and/or trigonid/talonid width, etc.

Repository: All fossils described and illustrated in this paper are catalogued as WIMF/A (Wadia

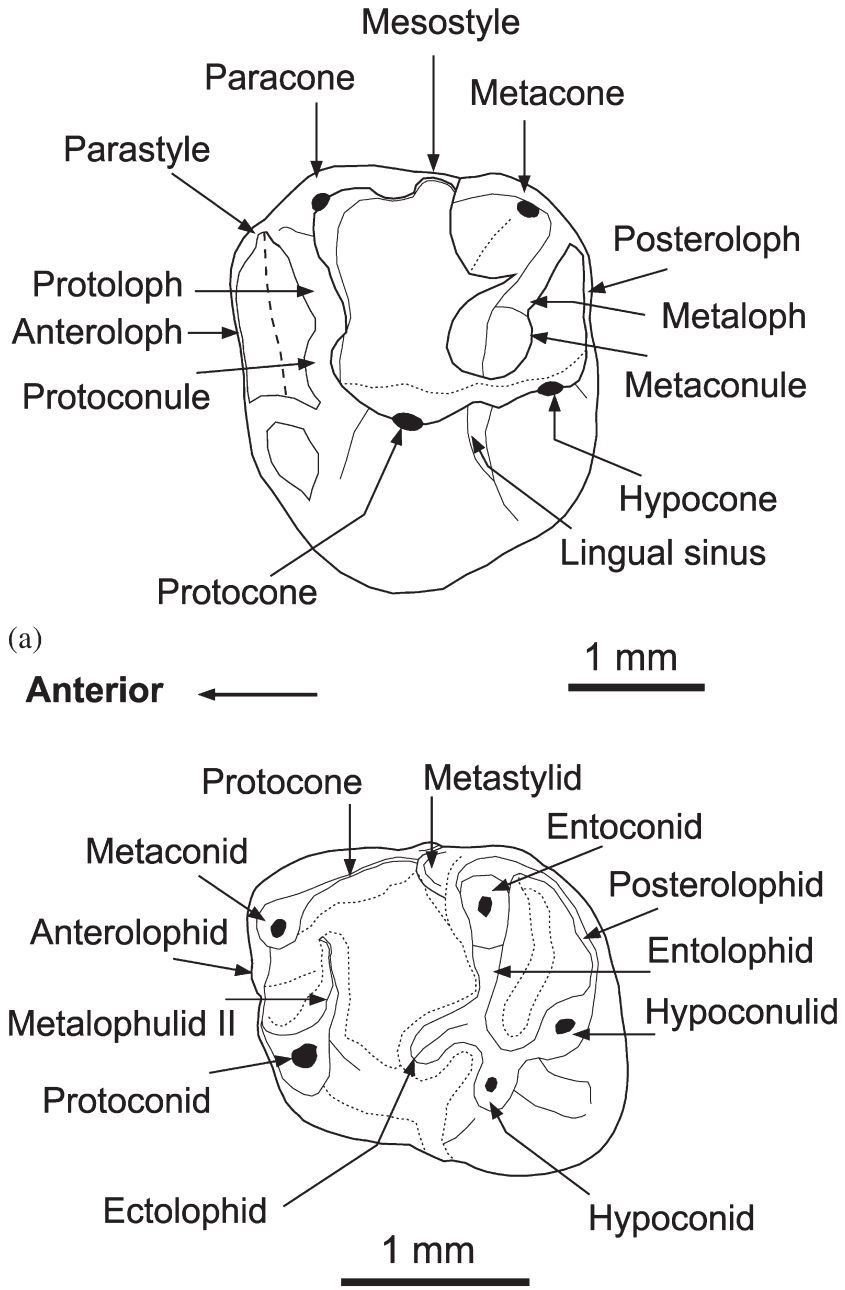

(b)

Figure 7. Dental terminology used for describing upper and lower molars. (a) Subathumys solanorius gen. et sp. nov., WIMF/A 1636 (holotype), LM2; (b) Chapattimyidae indet. 1, WIMF/A 1626, Lm1. Both specimens are from the older red beds (early Eocene) of the Subathu Formation.

Institute Microfossil Collection) numbers and stored in the repository of the Wadia Institute of Himalayan Geology at Dehradun (India).

\section{Systematic palaeontology}

Class: Mammalia Linnaeus 1758

Order: Rodentia Bowdich 1821

Superfamily: Ctenodactyloidea Tullberg 1899

Family: Chapattimyidae Hussain et al. 1978 (McKenna and Bell 1997)

\section{Genus Subathumys nov.}

Etymology: Named after 'Subathu', a cantonment town in the Solan District of Himachal Pradesh, near where the fossiliferous site is situated.

Type species: Subathumys solanorius sp. nov. 
Table 1. Measurements (in $\mathrm{mm}$ ) of isolated upper and lower cheek teeth of early Eocene rodents from the older red beds of the Subathu Formation, Solan District, Himachal Pradesh, northwestern sub-Himalaya, India.

\begin{tabular}{|c|c|c|c|c|c|c|}
\hline Genus and species & $\begin{array}{l}\text { Specimen } \\
\text { no. }\end{array}$ & Tooth & Length & Width & $\begin{array}{l}\text { Crown area } \\
(\mathrm{L} \times \mathrm{W})\end{array}$ & $\begin{array}{l}\text { Length-width } \\
\text { ratio }(\mathrm{L} / \mathrm{W})\end{array}$ \\
\hline Subathumys solanorius gen. et sp. nov. & WIMF/A 1636 & LM2 & 2.10 & 2.52 & 5.292 & 0.833 \\
\hline S. solanorius gen. et $\mathrm{sp}$. nov. & WIMF/A 1620 & RM1 & 2.00 & 2.24 & 4.480 & 0.892 \\
\hline S. globulus gen. et sp. nov. & WIMF/A 1635 & RM2 & 2.20 & 2.32 & 5.104 & 0.948 \\
\hline Birbalomys cf. sondaari & WIMF/A 1625 & RM1 & 2.04 & 2.32 & 4.733 & 0.879 \\
\hline Birbalomys sp. & WIMF/A 1622 & RP4 & 1.82 & 1.80 & 3.276 & 1.011 \\
\hline Birbalomys sp. & WIMF/A 1628 & LM1-2 & 1.56 & 1.84 & 2.870 & 0.847 \\
\hline Birbalomys sp. & WIMF/A 1621 & RM1-2 & 2.14 & $2.24^{*}$ & 4.793 & 0.955 \\
\hline Birbalomys sp. & WIMF/A 1633 & RM2 & 1.94 & 2.20 & 4.268 & 0.881 \\
\hline cf. Chapattimys sp. & WIMF/A 1623 & LP4 & 1.58 & 2.20 & 3.476 & 0.718 \\
\hline cf. Chapattimys sp. & WIMF/A 1629 & LM1 & 1.86 & 2.30 & 4.278 & 0.808 \\
\hline Chapattimyidae indet. 1 & WIMF/A 1626 & Lm1 & 1.96 & 1.78 & 3.488 & 1.101 \\
\hline Chapattimyidae indet. 1 & WIMF/A 1631 & $\mathrm{Rm} 3$ & 2.52 & 2.10 & 5.292 & 1.2 \\
\hline Chapattimyidae indet. 2 & WIMF/A 1627 & Lm1 & 2.08 & 1.74 & 3.619 & 1.195 \\
\hline Chapattimyidae indet. 2 & WIMF/A 1634 & Lm3 & 2.38 & 1.98 & 4.712 & 1.202 \\
\hline Chapattimyidae indet. 3 & WIMF/A 1632 & $\operatorname{Lm} 2$ & 1.48 & 1.52 & 2.249 & 0.973 \\
\hline Rodentia indet. & WIMF/A 1630 & P3 & 1.06 & 1.24 & 1.314 & 0.854 \\
\hline Rodentia indet. & WIMF/A 1624 & Rm2-3 & $2.08^{*}$ & $1.54^{*}$ & 3.203 & 1.350 \\
\hline
\end{tabular}

*Estimate based on reconstruction.

Diagnosis: Differs from Birbalomys and Chapattimys in having anterior upper molars with hypocone substantially smaller than protocone and not shifted lingually in relation to protocone and also in having an interrupted metaloph that converges towards the protocone, but does not join it. Similar to Meldimys musak from peninsular India in having a reduced hypocone and an externally extended mesostyle, but differs in lacking a crest that descends from the protocone into the trigon basin, possessing a weaker parastyle, stronger protoconule and an interrupted metaloph (not joined to protocone).

\section{Subathumys solanorius sp. nov.}

(Figure 8a, c; table 1)

Etymology: Solan+-orius, Latin, place (district of Solan) where the type locality is situated.

Holotype: WIMF/A 1636, an isolated left upper second molar (LM2).

Referred material: WIMF/A 1620, an isolated left upper first molar (RM1).

Horizon and locality: Lower Eocene (Ypresian) older Subathu red beds of the Subathu Formation of stratotype area, Subathu $\left(30^{\circ} 57^{\prime} 50^{\prime \prime} \mathrm{N}\right.$; $\left.76^{\circ} 58^{\prime} 33^{\prime \prime} \mathrm{E}\right)$, Solan District, Himachal Pradesh.

Diagnosis: Differs from Subathumys globulus in having anterior upper molars with normal rather than inflated lingual cusps, more reduced hypocone and in possessing a distinct mesostyle.

Description and remarks: M1-2 are characterized by their hypocone, which is substantially smaller than the protocone and is not shifted lingually in relation to the protocone. In fact, in the holotype (LM2), the protocone lobe clearly protrudes more lingually than the hypocone. In M2, the protocone and hypocone are more widely separated than in M1. The protocone is massive and the largest cusp; the paracone is larger than the metacone. The protoconule is smaller than the metaconule and lies on the protoloph closer to the protocone than to the paracone. The protoloph is complete unlike the metaloph, which converges towards the protocone but terminates at the metaconule rather than joining the protocone. The metaloph converges towards the midpoint on the endoloph rather than towards the apex of the protocone, making the trigon ' $U$ ' shaped unlike in other chapattimyids in which it is rather ' $\mathrm{V}$ ' shaped. The shelf between the anteroloph and protoloph is anteroposteriorly broad. The anteroloph terminates anterior to the apex of the protocone; the posteroloph is distinct and extends to the tip of the hypocone. The parastyle is weak, whereas the mesostyle is distinct and slightly lingually extended as in Meldimys. A pronounced sinus is situated between the protocone and the hypocone.

The ailuravine Meldimys and the yuomyid Advenimus are also known to have a reduced hypocone (smaller than the protocone). Subathumys differs clearly from Meldimys in lacking a crest that descends from the protocone into the trigon basin, in weaker parastyle, and in metaloph that does not join the protocone. In M1-2 referred to 


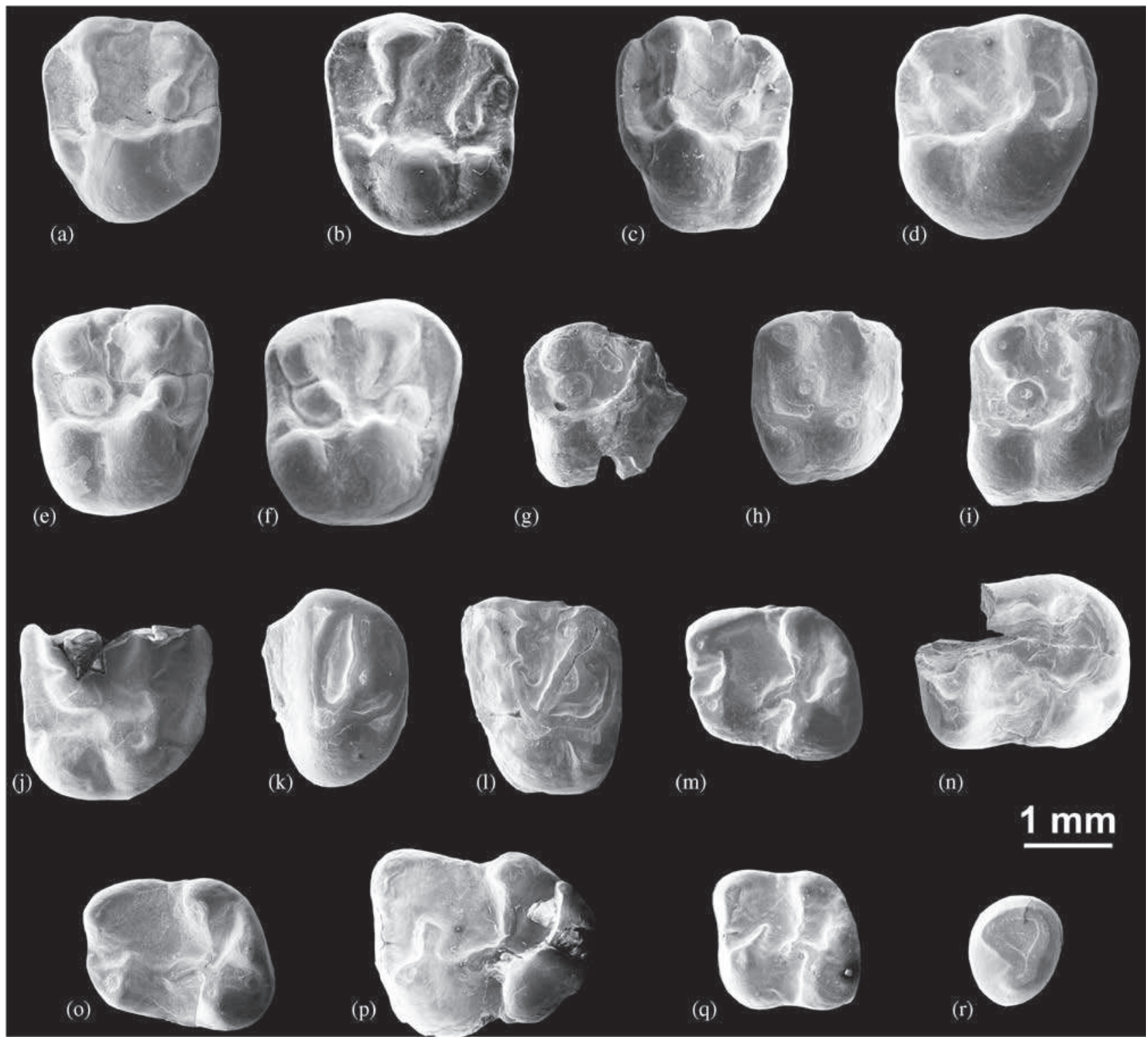

Figure 8. Isolated cheek teeth of chapattimyid rodents from the early Eocene older Subathu red beds, lower-middle part of the Subathu Formation, Subathu, Himachal Pradesh (India). Scale bars represent $1 \mathrm{~mm}$. (a-c) Subathumys solanorius gen. et sp. nov. (a, c) compared with cf. Petrokoslovia sp. indet. 1 (b) from the younger Subathu red beds, (a) left M2 (WIMF/A 1636); (b) left M2 (WIMF/A 1210); (c) right M1, reversed (WIMF/A 1620); (d) Subathumys globulus gen. et sp. nov., right M2 (WIMF/A 1635); (e-f) Birbalomys cf. sondaari (e) compared with Birbalomys sondaari (f) from the younger Subathu red beds, (e) right M1 (WIMF/A 1625); (f) left M1-2, reversed (WIMF/A 1187); (g-j) Birbalomys sp. (g) right P4 (WIMF/A 1622); (h) left M1-2, reversed (WIMF/A 1628); (i) right M2 (WIMF/A 1633); (j) right M1-2 (WIMF/A 1621); (k, l) cf. Chapattimys sp.; (k) left P4 (WIMF/A 1623); (l) left M1 (WIMF/A 1629); (m-n) Chapattimyidae indet. 1 (m) left $\mathrm{m} 1$ (WIMF/A 1626); (n) partly damaged right m3, reversed (WIMF/A 1631); (o-p) Chapattimyidae indet. 2 (o) left m1 (WIMF/A 1627); (p) left m3 (WIMF/A 1634); (q) Chapattimyidae indet. 3 left m2 (WIMF/A 1632); (r) Rodentia indet. P3 (WIMF/A 1630).

Advenimus cf. burkei by Averianov (1996), the metaconule is smaller than the metacone, and a distinct protoconule is present. It may be mentioned here that the attribution of some upper dentitions from the early Eocene of Kyrgyzstan to Advenimus by Averianov (1996) needs to be confirmed as opined by Dashzeveg and Meng (1998). The lower cheek teeth of $S$. solanorius gen. et sp. nov. are yet to be recognized.
The holotype M2 of Subathumys solanorius gen. et sp. nov. has a striking morphological and metrical resemblance with a tooth described as cf. Petrokoslovia sp. indet. 1 from the middle Eocene beds of the Subathu Formation of Kalakot area in Jammu and Kashmir, India (Kumar et al. 1997b; Plate 3, figure 31). However, the tooth from Kalakot (WIMF/A 1210, figure 8b) has a more pronounced anteroloph that extends lingually up to the base of 
protocone rather than terminating anterior to the apex of protocone. Further, it has a small ledge-like lingual cingulum between protocone and hypocone, an anteroposteriorly broader shelf between the anteroloph and protoloph, a stronger parastyle, a smaller metacone, an interrupted endoloph and weaker protoconule-protocone connection. It is possible that the two specimens may turn out to be congeneric/conspecific when additional material is found and studied. Petrokoslovia (=Petrokozlovia) is a yuomyid known from the middle Eocene of Mongolia and Kazhakstan (Shevyreva 1972, 1976). Petrokoslovia is characterized by a weak hypocone which is at the same level as the protocone and not lingually or labially shifted, lack of metaconule-protocone connection, protoconule submerged in protoloph to absent, and a well-developed parastyle (Marivaux et al. 2004). In Subathumys solanorius gen. et sp. nov., the hypocone is not at the same level as the protocone but somewhat labially positioned and the parastyle is weaker.

\section{Subathumys globulus sp. nov.}

(Figure 8d; table 1)

Etymology: Epithet 'globulus' refers to globular shape of tooth with inflated lingual cusps.

Holotype: WIMF/A 1635, an isolated right upper second molar (RM2).

Horizon and locality: Lower Eocene (Ypresian) older Subathu red beds of the Subathu Formation of stratotype area, Subathu $\left(30^{\circ} 57^{\prime} 50^{\prime \prime} \mathrm{N}\right.$; $\left.76^{\circ} 58^{\prime} 33^{\prime \prime} \mathrm{E}\right)$, Solan District, Himachal Pradesh.

Diagnosis: Differs from Subathumys solanorius in having globular anterior upper molars with inflated lingual cusps, less reduced hypocone and in lacking a mesostyle.

Description and remarks: M2 is globular with noticeably inflated (bunodont) protocone and hypocone, which are well separated from each other. The protocone is the largest and highest cusp; the hypocone is smaller than the protocone, but less than in Subathumys solanorius. The paracone is larger than metacone and the two cusps are more widely separated from each other than in $S$. solanorius (figure $8 \mathrm{a}, \mathrm{c}$ ) and Birbalomys sp. (figure $8 \mathrm{~g}-\mathrm{j})$. A mesostyle is absent or indistinct. An apparently large protoconule is incorporated in the protoloph. The metaconule is larger than the protoconule; it is massive and somewhat transverse than the roundish and conical one in S. solanorius. The metaloph is directed towards the apex of the protocone, but it terminates at the metaconule and does not join the protocone. The valley between the protoloph and anteroloph is anteroposteriorly broad and nearly as deep as the trigon basin. The anteroloph does not join the apex of the protocone but terminates much below and anterior to it. The lingual sinus between the protocone and the hypocone is shallower and more open than in Subathumys solanorius and Birbalomys sp. The lower cheek teeth of $S$. globulus gen. et sp. nov. are yet to be recognized.

Birbalomys cf. sondaari (Hussain et al. 1978) (Figure 8e; table 1)

Referred material: WIMF/A 1625, an isolated right upper first molar (RM1).

Horizon and locality: Lower Eocene (Ypresian) older Subathu red beds of the Subathu Formation of stratotype area, Subathu $\left(30^{\circ} 57^{\prime} 50^{\prime \prime} \mathrm{N}\right.$; $\left.76^{\circ} 58^{\prime} 33^{\prime \prime} \mathrm{E}\right)$, Solan District, Himachal Pradesh.

Description and remarks: WIMF/A 1625, an unworn M1 differs from all other anterior molars in the collection in possessing an interrupted protoloph and a large inflated protoconule, which is isolated from the paracone but connected to the protocone. Its metaconule is also inflated, nearly as large as the metacone and a little larger than the protoconule. The metaconule is slightly isolated from the metacone and widely isolated from the protocone. The protoloph is interrupted; its labial part after descending from the paracone lingually towards the protoconule, turns posteriorly, terminating into the trigon basin rather than joining the protoconule, which is connected to the protocone. This tooth has striking morphological and metrical resemblance with the anterior molars of the middle Eocene chapattimyid Birbalomys sondaari (Kumar et al. 1997b; Plate 2, figures 7-9) in the position and morphology of protoconule and protoloph, but teeth of the latter taxon differ in having (i) a hypocone clearly lingually shifted in relation to protocone, (ii) a metaconule, which is weakly connected to the protocone, (iii) a weaker parastyle, (iv) the shelf between the protoloph and anteroloph anteroposteriorly broader, and (v) an anteroloph, which extends lingually up to the base of the protocone rather than terminating on protocone (figure 8f).

The morphological differences between the anterior molars of $B$. sondaari and the tooth described here may just be representing intraspecific variation, but the same cannot be said conclusively until additional material is forthcoming.

Birbalomys sp. (Sahni and Khare 1973)

(Figure $8 \mathrm{~g}-\mathrm{j}$; table 1)

Referred material: WIMF/A 1621, an isolated partly damaged right upper M1-2; WIMF/A 1622, an isolated right upper fourth premolar (RP4); WIMF/A 1628, an isolated left upper first or second molar (LM1-2); WIMF/A 1625 right upper 
first molar (RM1); WIMF/A 1633, isolated right upper second molar (RM2).

Horizon and locality: Lower Eocene (Ypresian) older Subathu red beds of the Subathu Formation of stratotype area, Subathu $\left(30^{\circ} 57^{\prime} 50^{\prime \prime} \mathrm{N}\right.$; $\left.76^{\circ} 58^{\prime} 33^{\prime \prime} \mathrm{E}\right)$, Solan District, Himachal Pradesh.

Description and remarks: The cheek teeth have close morphological similarity with the teeth of various species of the middle Eocene rodent Birbalomys. However, they differ from the known species of Birbalomys mainly in possessing an interrupted metaloph as opposed to an uninterrupted one in the latter taxon. P4 is nearly as long as broad, whereas M1-2 are broader than long. P4 and M1-2 have subequal protocone and hypocone; hypocone is slightly shifted further lingually in relation to the protocone or is at the same level as the protocone. Metaloph converges towards the protocone, but does not join it; it is connected to the metacone. An indistinct protoconule is incorporated into the protoloph, which is complete. A mesostyle is present, but unlike the case in Subathumys solanorius it is not extended externally. The posteroloph is higher than the anteroloph and is connected to the hypocone without any sinus in between. The anteroloph joins the anterior arm of protocone. A parastyle is present.

WIMF/A 1621 (RM1-2) is squarish and lacks its labial part, including apices of paracone and metacone; metaconule is large; metaloph converges towards the protocone and appears weakly connected to it. The tooth is characterized by the presence of a distinct lingual sinus between the posteroloph and the hypocone unlike the situation in Chapattimys and Subathumys. In this respect as well as in general, this tooth is similar to M2 in the holotype of Birbalomys woodi (Kumar et al. 1997b; Plate 1, figure 1).

Teeth of Birbalomys sp. differ from those of Subathumys solanorius gen. et sp. nov. in having subequal hypocone and protocone on $\mathrm{P} 4-\mathrm{M} 2$, from Subathumys globulus gen. et sp. nov. in having rectangular rather than globular upper cheek teeth with normal rather than inflated lingual cusps and possessing a mesostyle, and from the known species of Chapattimys in having (i) an interrupted metaloph, which is not connected to the protocone, (ii) a hypocone, which is almost at the same level as the protocone rather than being markedly lingually shifted, and (iii) in being not so lophate. A definitive taxonomic (specific) assignment of fossils referred here to Birbalomys sp. will be attempted when more teeth are recovered.

cf. Chapattimys sp. (Hussain et al. 1978)

(Figure 8k, l; table 1)
Referred material: WIMF/A 1623, an isolated left upper P4; WIMF/A 1629, an isolated left upper M1.

Horizon and locality: Lower Eocene (Ypresian) older Subathu red beds of the Subathu Formation of stratotype area, Subathu ( $\left.30^{\circ} 57^{\prime} 50^{\prime \prime} \mathrm{N} ; 76^{\circ} 58^{\prime} 33^{\prime \prime} \mathrm{E}\right)$, Solan District, Himachal Pradesh.

Description and remarks: Cheek teeth differ from those of Subathumys, Birbalomys cf. sondaari and Birbalomys sp. described here in possessing an uninterrupted metaloph and are similar to known species of Birbalomys and Chapattimys on this feature. Metaloph converges towards the protocone and is clearly connected to it. Protoconule is indistinct, probably incorporated in the protoloph. WIMF/A 1623 and 1629 are more transverse (broader than long) than the teeth of Birbalomys, but are similar to those of Chapattimys in being distinctly lophate. $\mathrm{P} 4$ is characterized by its roundish posterior margin and rather closely placed paracone and metacone making the trigon basin very narrow with a biconvex outline rather than ' $\mathrm{V}$ ' shaped. It has some resemblance with the $\mathrm{P} 4$ of Chapattimys wilsoni described by Hussain et al. (1978; Plate 4, figure 1) from the middle Eocene of Pakistan, but differs in being over $20 \%$ larger, having more closely situated paracone and metacone and in possessing a larger metaconule, which is not incorporated in the metaloph. The M1 is quite worn with a somewhat lingually protruded hypocone, a large metaconule and distinct ' $\mathrm{V}$ ' shaped and uninterrupted protoloph and metaloph giving the tooth a lophate appearance. Due to its much worn nature, it is difficult to compare it with the known species of Chapattimys. However, in size it compares well with $C$. debruijni.

Chapattimyidae indet. 1 (Hussain et al. 1978) (Figure $8 \mathrm{~m}, \mathrm{n}$; table 1)

Referred material: WIMF/A 1626, an isolated left lower first molar (Lm1); WIMF/A 1631, partly damaged right lower third molar (Rm3).

Horizon and locality: Lower Eocene (Ypresian) older Subathu red beds of the Subathu Formation of stratotype area, Subathu ( $\left.30^{\circ} 57^{\prime} 50^{\prime \prime} \mathrm{N} ; 76^{\circ} 58^{\prime} 33^{\prime \prime} \mathrm{E}\right)$, Solan District, Himachal Pradesh.

Description and remarks: The $\mathrm{m} 1$ shows a mix of chapattimyid and yuomyid characters: hypoconulid and hypoconid situated closer together and connected by a ridge; hypoconulid and entoconid situated wider apart, but connected by the posterolophid; entolophid nearly transverse and joins the ectolophid; mesoconid indistinct; ectolophid curved and incomplete, terminates at the posterior slope of protoconid; posterior arm of metaconid long and high; a small metastylid present between metaconid and entoconid; metalophulid II well developed, high 
and straight/transverse (rather than directed towards entoconid) extending to the posterolabial slope of metaconid thus closing the trigonid basin from the talonid. Among the known chapattimyids, WIMF/A 1626 has considerable morphological resemblance with the m1 (WIMF/A 1148) of Birbalomys vandermeuleni from the middle Eocene of Kalakot (Kumar et al. 1997b; Plate 3, figure 2), in features like short ectolophid and long and high posterior arm of metaconid. However, the $\mathrm{m} 1$ of $B$. vandermeuleni is substantially smaller and also differs in possessing a prominent cingular ledge between the hypoconid and hypoconulid.

WIMF/A 1631, a rather large $\mathrm{m} 3$ is characterized by its rectangular shape and differs from the other m3 (WIMF/A 1634, Chapattimyidae indet. 2 ) in the collection in being posteriorly as wide as anteriorly, rather than narrower. Further, its hypoconulid and entoconid are connected by a high posterolophid, entolophid or hypolophid is very weak to absent, and the anterior arm of entoconid is characteristically higher and longer. A distinct hypoconulid is incorporated in the posterolophid. A small mesostylid is present. An ectolophid appears more complete than in other lower teeth and extends almost to the apex of the protoconid. A part of the tooth with metaconid is missing. WIMF/A 1631 has some morphological resemblance with m3 (WIMF/A 1146) of $B$. vandermeuleni from the middle Eocene of Kalakot (Kumar et al. 1997b; Plate 3, figure 4), particularly in features like overall shape of tooth, high posterolophid incorporating hypoconulid and high and long anterior arm of entoconid, however, the $\mathrm{m} 3$ of latter species is substantially smaller with a posteriorly protruded hypoconulid lobe.

Chapattimyidae indet. 2 (Hussain et al. 1978) (Figure 8o, p; table 1)

Referred material: WIMF/A 1627, an isolated left lower first molar (Lm1); WIMF/A 1634, an isolated left lower third molar (Lm3).

Horizon and locality: Lower Eocene (Ypresian) older Subathu red beds of the Subathu Formation of stratotype area, Subathu $\left(30^{\circ} 57^{\prime} 50^{\prime \prime} \mathrm{N}\right.$; $\left.76^{\circ} 58^{\prime} 33^{\prime \prime} \mathrm{E}\right)$, Solan District, Himachal Pradesh.

Description and remarks: WIMF/A 1627 is of the same size as another $\mathrm{m} 1$ in the collection (WIMF/A 1626, Chapattimyidae indet. 1) described above, but differs mainly in having (i) a hypoconulid almost equidistant from hypoconid as well as entoconid (=postero-centrally placed) rather than being closer to hypoconid, (ii) a hypoconulid that is connected neither to hypoconid nor to entoconid, i.e., posterolophid is absent, (iii) slightly posteriorly directed entolophid that does not join the ectolophid, (iv) a rather straight ectolophid with a small mesostylid, and (v) a weaker and shorter metalophulid II that does not extend as far towards the metaconid leaving the trigonid open posteriorly. A metastylid is not discernible. WIMF/A 1627 shows considerable morphological and metrical resemblance with m1-2 (WIMF/A 1199) of Birbalomys sondaari from the middle Eocene of Kalakot (Kumar et al. 1997b; Plate 2 , figure 3 ), especially in postero-centrally placed hypoconulid, however, the latter has more bunodont cusps. Differs from both Birbalomys and Chapattimys in having shorter ectolophid and in lacking hypoconulid-entoconid connection (posterolophid).

The m3 is posteriorly narrower substantially as in Birbalomys and Chapattimys with a massive protoconid, a large metaconid and a hypoconulid well separated from the hypoconid as well as the entoconid. It is somewhat larger to go with the two $\mathrm{m} 1 \mathrm{~s}$ in the collection and more so with the lone $\mathrm{m} 2$. Yet it has been provisionally associated with one of the two m1s (WIMF/A 1627) based on similarities like a transverse entolophid that joins the thicker ectolophid, well separated hypoconid and hypoconulid, and a similarly oriented but longer metalophulid II. The morphology and size of the present $\mathrm{m} 3$ is broadly similar to those of Birbalomys. It differs from $\mathrm{m} 3$ of $B$. woodi in being shorter and less narrower posteriorly, and in possessing a stronger entolophid and a nearly straight metalophulid II.

Chapattimyidae indet. 3 (Hussain et al. 1978) (Figure 8q; table 1)

Referred material: WIMF/A 1632, an isolated left lower second molar (Lm2).

Horizon and locality: Lower Eocene (Ypresian) older Subathu red beds of the Subathu Formation of stratotype area, Subathu $\left(30^{\circ} 57^{\prime} 50^{\prime \prime} \mathrm{N}\right.$; $\left.76^{\circ} 58^{\prime} 33^{\prime \prime} \mathrm{E}\right)$, Solan District, Himachal Pradesh.

Description and remarks: WIMF/A 1632 (m2) is considerably smaller than both the m1s (WIMF/A 1626 and WIMF/A 1627) and m3s (WIMF/A 1631 and WIMF/A 1634) as well as most upper teeth, except P3, in the collection and hence almost certainly represents a distinct taxon. Morphologically, it is more akin to WIMF/A 1626 (Chapattimyidae indet. 1, figure 8m) than to WIMF/A 1627 (Chapattimyidae indet. 2, figure 8o) except in possessing a shorter metalophulid II, which is directed towards the entoconid rather than towards the metaconid, a lower posterolophid between entolophid and hypoconulid, a shorter ectolophid, and in lacking a metastylid. A mesostylid is apparently absent. 
Among the known chapattimyids, the present tooth is comparable, in size, only to the middle Eocene taxa Birbalomys ijlsti and to a lesser extent to $B$. vandermeuleni. However, morphologically, it displays closer resemblance to the $\mathrm{m} 2$ of B. vandermeuleni (Kumar et al. 1997b, Plate 3, figure 3), particularly in the development and orientation of entolophid and metalophulid II, hypoconid-hypoconulid connection and a shorter ectolophid, but differs in being almost squarish, lacking a mesostylid (on the ectolophid) possessing a cingular ledge between the protoconid and the hypoconid and in possessing a distinct cingular ledge below the hypoconid-hypoconulid.

Rodentia indet. (Bowdich 1821) (Figure 8r; table 1)

Referred material: WIMF/A 1630, an isolated upper third premolar (P3).

Horizon and locality: Lower Eocene (Ypresian) older Subathu red beds of the Subathu Formation of stratotype area, Subathu $\left(30^{\circ} 57^{\prime} 50^{\prime \prime} \mathrm{N}\right.$; $\left.76^{\circ} 58^{\prime} 33^{\prime \prime} \mathrm{E}\right)$, Solan District, Himachal Pradesh.

Description and remarks: P3 is rather large and well preserved. Among the Eocene rodents from the Indo-Pakistan region, a P3 is known only for the middle Eocene chapattimyid Birbalomys woodi, in which it is preserved with other teeth in the holotype skull (Sahni and Khare 1973). Compared to $\mathrm{P} 4$, the present $\mathrm{P} 3$ is not as small as of $B$. woodi, which appears as a rudimentary peg-like tooth without evidence of any occlusion (Sahni and Khare 1973; Kumar et al. 1997b; Plate 1, figure 1). In contrast, the present P3 has a distinct occlusal morphology, indicating its functional nature (figure 8r). A P3 is present in all ctenodactyloid families (Cocomyidae, Chapattimyidae, Yuomyidae, Tamquamyidae) except Ctenodactylidae (Wang 1994). Based on size, the present P3 could well go with either of the taxa described here except perhaps Chapattimyidae indet. 3, which is represented by a rather small $\mathrm{m} 2$.

\section{Discussion}

\subsection{Composition of early Eocene rodent assemblages from South Asia}

There are now three early Eocene rodent assemblages known from the Indian subcontinent: (i) Vastan assemblage from the Cambay Shale Formation, Gujarat, peninsular India (Bajpai et al. 2007; Rana et al. 2008), (ii) Subathu assemblage from the Subathu Formation, northwestern India (this work), and (iii) Barbara Banda assemblage from the Mami Khel Clay in northern Pakistan (De
Bruijn et al. 1982). The Vastan rodent assemblage is known by $\sim 20$ isolated cheek teeth mostly referable to an ailuravine ischyromyid, Meldimys musak (Rana et al. 2008).

Among the other rodent teeth documented from the Cambay Shale Formation of Vastan area, a rather large $\mathrm{P} 4$ was referred to a new ctenodactyloid, Anthramys vastani and a considerably smaller M1-2 to an indeterminate taxon having close affinity with the Chapattimyidae (Bajpai et al. 2007). The $\mathrm{P} 4$ of A vastani is characterized by its globular and sub-molariform shape, an indistinct or missing hypocone, uninterrupted protoloph and metaloph with distinct protoconule and metaconule, and a transverse crest that originates from the protoloph and extends anteriorly to join the anteroloph dividing the valley between anteroloph and protoloph (Bajpai et al. 2007; figure $2 \mathrm{a}-\mathrm{c}$ ). It differs clearly from the $\mathrm{P} 4 \mathrm{~s}$ of ctenodactylids and cocomyids in being submolariform, from chapattimyid $\mathrm{P} 4 \mathrm{~s}$ in lacking a hypocone and from yuomyid $\mathrm{P} 4 \mathrm{~s}$ in possessing an uninterrupted metaloph. Size-wise, it is comparable to the P4 of Meldimys musak (Rana et al. 2008, figure $3 \mathrm{~b}$ ) though it is slightly more transverse (length/width $=1.71 / 2.36 \mathrm{~mm}$ as against $1.7 / 2.0$ in M. musak). In occlusal morphology as well, it has similarities with M. musak, particularly in reduced hypocone, and uninterrupted protoloph and metaloph with distinct protoconule and metaconule. Two other important features noted by Bajpai et al. (2007) on $\mathrm{P} 4$ of $A$. vastani are: somewhat closely placed metacone and paracone, and the presence of a short arcuate crest that descends labially from the metacone. While the labial crest mentioned by Bajpai et al. (2007) could be a part of the externally extended mesostyle, which is characteristically present in $M$. musak, the paracone and metacone do not appear to be particularly closely placed in the latter species. However, a right $\mathrm{P} 4$ of another ailuravine, $M$. louisi from the early Eocene of Avenay in the Paris Basin (Escarguel 1999; Plate 3e) is also globular and has similarly closely placed paracone and metacone like in the $\mathrm{P} 4$ of $A$. vastani. Therefore, although A. vastani sample is inadequate to determine its precise affinity, it is likely that $A$. vastani represents an ailuravine, possibly $M$. musak. The other tooth (M1-2) described by Bajpai et al. (2007) as cf. Chapattimyidae gen. et sp. indet. (Bajpai et al. 2007; figure $2 \mathrm{f}-\mathrm{h}$ ) is morphologically closely similar to M1s of M. musak (Rana et al. 2008, figure 3c-d) though metrically smaller. Its length/width, as recorded by Bajpai et al. (2007), are 1.41/1.38 mm as against $1.9 / 2.15$ and $2.1 / 2.5 \mathrm{~mm}$ for two M1s of M. musak. This tooth certainly represents an ailuravine, most likely $M$. musak, or a smaller species of Meldimys. Thus no chapattimyid, or any rodent 
other than ailuravines appears to be present in the collections known so far from the early Eocene beds of Vastan (Gujarat) in peninsular India.

The Barbara Banda rodent assemblage from the Mami Khel Clay of Kohat in Pakistan is represented by just three isolated teeth, of which two (P4 and M1-2) have been referred to distinct but unnamed cocomyids and the third (p4) to an indeterminate paramyine (Ischyromyidae) by De Bruijn et al. (1982). The attribution of a robust non-molariform P4 and a rather lophodont and smaller M1-2 to two distinct cocomyids appears to be justified. However, the attribution of a $\mathrm{p} 4$ (De Bruijn et al. 1982; figure 6) to an indeterminate paramyine is debatable as also opined by Rana et al. (2008), who compared it with p4s of known ischyromyoids from Europe and North America and concluded that it represented neither a paramyine nor a reithroparamyine (inclusive of Microparamys). The morphology and metrics of this p4 suggest that it could actually represent an ailuravine, or more likely a pseudoparamyine, both of which probably shared the same biogeographical history.

The early Eocene Subathu rodent assemblage documented here from the older red beds of the Subathu Formation in the northwest sub-Himalaya is distinct and more diverse than the aforementioned assemblages from Vastan and Barbara Banda. It comprises 17 cheek teeth referable to two new and three other taxa showing clear affinities with chapattimyids and yuomyids. Interestingly, there are no ailuravines, cocomyids, paramyines or pseudoparamyines in the Subathu assemblage. One of the reasons for this difference in composition of the early Eocene rodent assemblages from Subathu, Vastan and Barbara Banda could be due to the difference in their respective ages (table 2).

Apart from the difference in age, the absence of ailuravines in the sub-Himalayan sections could also be attributed to (i) the early Eocene beds coeval to those of Vastan have not been sampled yet in the Himalayan region - this is likely because there appear to be no continental beds of an early Ypresian age in the sub-Himalayan region, (ii) for an unknown reason ailuravines failed to disperse to the Himalayan region even though other small mammals such as diacodexeid artiodactyls could do so, and (iii) ailuravines did not survive beyond early-early Eocene. Likewise, the absence of chapattimyids in the Vastan rodent assemblage could also be due to two reasons: (i) the chapattimyids, like raoellid artiodactyls and anthracobunid perissodactyls originated in the sub-Himalayan region in specific environmental conditions created by the shrinking and shallowing of Tethys Sea and did not disperse into other areas, including peninsular
India, and (ii) the chapattimyids appeared in the later part of the early Eocene (=late Ypresian), which is yet to be sampled in peninsular India. For further insights, it is important to investigate the late Paleocene, basal Eocene and younger early Eocene terrestrial horizons of the peninsular India as well as of the sub-Himalayan region.

The co-occurrence in the early Eocene rodent assemblage from Subathu of at least three or more chapattimyids of substantially different size and morphology indicates their early radiation in this fauna. Such diversity is clearly more compared to other coeval assemblages from the subcontinent and the reasons for this are presently hard to understand. Were there some islands in the close vicinity of India that may have supported diverse rodents in advance of the later invasions from Asia to India?

\subsection{Chronology of early Eocene rodent assemblages from South Asia}

The ages of the three early Eocene rodent assemblages from the Indian subcontinent are apparently distinct as also corroborated by their taxonomic composition. The likely chronology is depicted in table 2. The Vastan rodent assemblage is well constrained at $\sim 54-53$ Ma (early Ypresian) based on foraminiferal biostratigraphy and the occurrence of age-diagnostic dinoflagellate cyst assemblage (Sahni et al. 2006; Garg et al. 2008; Punekar and Saraswati 2010). This is also corroborated by the mammalian fauna recorded thus far from the same stratigraphic level (Smith et al. 2007; Rose et al. 2009a, b, 2013, 2014; Kumar et al. 2010).

As regards to the age of the Barbara Banda assemblage, there is some ambiguity. It was originally considered as broadly of an early Eocene age (De Bruijn et al. 1982). Later studies, including a recent one, supported late-early Eocene or even early-middle Eocene ages (Gingerich et al. 1983; Thewissen et al. 1983; Pivnik and Wells 1996; Khan and Clyde 2013). However, Leinders et al. (1999) based on faunal associations in different Eocene localities of Pakistan and primitive nature of rodents and of the associated diacodexeid artiodactyl, Diacodexis pakistanensis from Barbara Banda determined early part of the early Eocene or the earliest Eocene age. The possibility of the so called 'paramyine' p4 from Barbara Banda actually being an ailuravine or more likely a pseudoparamyine as discussed earlier does not seem to reflect much on the precise age of the assemblage. However, it does indicate that Barbara Banda rodents are older than early-middle Eocene and likely also older than the early Eocene Subathu rodents. This is because ailuravines and pseudoparamyines are present neither in the 
Table 2. Chronology and taxonomic composition of Eocene rodent assemblages of the Indian subcontinent (composition follows classification by McKenna and Bell 1997).

\begin{tabular}{|c|c|c|}
\hline Age & Horizons and localities & Composition \\
\hline $\begin{array}{l}\text { Middle Eocene } \\
\text { (Lutetian) }\end{array}$ & $\begin{array}{l}\text { (i) Younger red beds, Subathu Formation, } \\
\text { Kalakot, Rajauri District (Jammu and } \\
\text { Kashmir) and Subathu, Solan District } \\
\text { (Himachal Pradesh), NW sub-Himalaya, } \\
\text { India (Sahni and Khare 1973; Sahni and } \\
\text { Srivastava 1976; Kumar et al. 1997a, b) } \\
\text { (ii) Kuldana Formation, Ganda Kas, Punjab, } \\
\text { Pakistan (Hussain et al. 1978) }\end{array}$ & $\begin{array}{l}\text { Chapattimyidae } \\
\text { (=Chapattimyidae+Yuomyidae) } \\
\text { Chapattimyinae } \\
\text { Birbalomys woodi } \\
\text { B. sondaari } \\
\text { B. vandermeuleni } \\
\text { B. lavocati } \\
\text { B. ijlsti } \\
\text { Chapattimys debruijni } \\
\text { C. ibrahimshahi } \\
\text { C. wilsoni } \\
\text { C. asifi ( Gumbatomys asifi) } \\
\text { Yuomyinae } \\
\text { cf. Advenimus bohlini } \\
\text { cf. Petrokoslovia } \text { sp. indet. } 1 \\
\text { cf. Petrokoslovia } \text { sp. indet. } 2\end{array}$ \\
\hline $\begin{array}{l}\text { Early Eocene } \\
\text { (late Ypresian) }\end{array}$ & $\begin{array}{l}\text { Older red beds, Subathu Formation, Subathu, } \\
\text { Solan District (Himachal Pradesh), } \\
\text { NW sub-Himalaya, India (Present work) }\end{array}$ & $\begin{array}{l}\text { Chapattimyidae } \\
\text { (=Chapattimyidae+Yuomyidae) } \\
\text { Subathumys solanorius } \\
\text { S. globulus } \\
\text { Birbalomys cf. sondaari } \\
\text { Birbalomys sp. } \\
\text { cf. Chapattimys sp. } \\
\text { Chapattimyidae indet. }\end{array}$ \\
\hline $\begin{array}{l}\text { Early Eocene } \\
\text { (?early-middle Ypresian) }\end{array}$ & $\begin{array}{l}\text { Mami Khel Clay, Barbara Banda, Kohat, } \\
\text { Pakistan (De Bruijn et al. 1982) }\end{array}$ & $\begin{array}{l}\text { Cocomyidae } \\
\text { Genus A sp. I } \\
\text { Genus A sp. II } \\
\text { ?Pseudoparamyinae } \\
\text { (Ischyromyidae) } \\
\text { Gen. et sp. indet. }\end{array}$ \\
\hline $\begin{array}{l}\text { Early Eocene } \\
\text { (early Ypresian) } \\
\sim 54-53 \mathrm{Ma}\end{array}$ & $\begin{array}{l}\text { Cambay Shale Formation, Vastan (Surat } \\
\text { District, Gujarat), peninsular India } \\
\text { (Bajpai et al. 2007; Rana et al. 2008) }\end{array}$ & $\begin{array}{l}\text { Ailuravinae } \\
\text { (Ischyromyidae) } \\
\text { Meldimys musak }\end{array}$ \\
\hline
\end{tabular}

early middle Eocene localities of Indo-Pakistan (Kalakot, Metka, Ganda Kas, Chorlakki) nor in the older Subathu assemblage described here (table 2).

The age of the Subathu rodents treated here is almost certainly late-early Eocene (late Ypresian), as indicated by the foraminiferal biostratigraphy (Mathur and Juyal 2000). It is clearly younger than that of the Vastan assemblage and is closer to the youngest known Eocene (Lutetian or earlymiddle Eocene) rodent assemblages from India and Pakistan, as also corroborated by their similar familial and in some cases generic affinities and the presence of a combination of chapattimyid and yuomyid characters in the presently described teeth from the older Subathu red beds (Sahni and Khare 1973; Hussain et al. 1978; Kumar et al. 1997a, b).

\subsection{Familial status of early Eocene Subathu rodents}

The new Subathu rodents described here exhibit a combination of chapattimyid (Ch) and yuomyid $\mathrm{Yu}$ ) characters rather than characters of a single family as in case of Vastan rodents (Ischyromyidae) or those from the middle Eocene levels of the Subathu and Kuldana Formations (Chapattimyidae and Yuomyidae). For example: (i) in all but two upper cheek teeth in the present collection, the metaconule is quite inflated (Ch) but it does not join the protocone, leaving the metaloph incomplete/interrupted $(\mathrm{Yu})$, whereas in two other teeth (WIMF/A 1623 and 1629) the metaloph is clearly connected to the protocone $(\mathrm{Ch})$ and in another (WIMF/A 1621) it is weakly connected to the protocone $(\mathrm{Ch})$, (ii) in all except two teeth, the 
protocone and hypocone are subequal in size $(\mathrm{Ch})$, while in two other teeth (WIMF/A 1620 and 1636), the hypocone is considerably smaller than the protocone (Yu), (iii) in a few teeth (e.g., WIMF/A 1622,1628 and 1629), the position of hypocone is more lingual in relation to protocone $(\mathrm{Ch})$, whereas in others it is nearly at the same level as the protocone $(\mathrm{Yu})$, (iv) in all except one tooth, the protoconule is indistinct and merged with the protoloph (a character common to chapattimyids and yuomyids), however, in another tooth (WIMF/A 1625) the protocone is quite inflated and not merged with protoloph. Both the $\mathrm{P} 4 \mathrm{~s}$ in the collection are molariform as in chapattimyids as well as yuomyids. Like the upper teeth, lower molars also show a mixture of chapattimyid and yuomyid characters: (i) in two molars (WIMF/A 1626 and 1631), the hypoconulid and entoconid are connected by posterolophid as in chapattimyids, whereas in the other three (WIMF/A 1627, 1632 and 1634), these conids are separated by a valley as in yuomyids, (ii) in four teeth (WIMF/A 1627, 1631, 1632 and 1634), the metalophulid II is short and weak as in chapattimyids and yuomyids, but in one tooth (WIMF/A 1626), it is longer and prominent terminating near the metaconid, (iii) in most teeth, the anterior arm of entoconid is either absent or small as in chapattimyids and yuomyids, but in one m3 (WIMF/A 1631) it appears conspicuously high. The lower premolars, whose size and shape are important characters to distinguish chapattimyids $(=\mathrm{p} 4$ smaller or subequal to $\mathrm{m} 1$ and oval $)$ from yuomyids $(=\mathrm{p} 4$ larger than $\mathrm{m} 1$ and wasted) are unfortunately not represented in our collection.

The ctenodactyloid families Chapattimyidae and Yuomyidae were found on fossils from the early middle Eocene horizons (Hussain et al. 1978; Hartenberger 1982; Dawson et al. 1984; Kumar et al. $1997 \mathrm{a}, \mathrm{b})$. In fact, during the middle Eocene, the central and eastern Asiatic rodents were dominated by the Yuomyidae and the south Asiatic by the Chapattimyidae, which have been labelled as vicars of Yuomyidae and Ctenodactylidae by Flynn et al. (1986). Their diagnostic characters are more or less identical and the main differences are in size and shape of $\mathrm{p} 4 \mathrm{~s}$, inflated or otherwise shape of metaconule, complete/uninterrupted or incomplete/interrupted metaloph, size and the position of hypocone in respect to protocone, etc. (Wang 1994; Marivaux et al. 2004). According to Hartenberger (1982) and Dawson et al. (1984), the similarities between the chapattimyids and yuomyids are mostly in primitive characters and the two are distinct otherwise. Wang (1994) opined that these two families may belong to a single family, Chapattimyidae, though she refrained from merging the two due to inadequate data on Chapattimyidae. Following Wang (1994),
Averianov (1996) broadened the definition of Chapattimyidae to include Yuomyidae into it. This arrangement, however, was not followed by some of the later workers (e.g., Dashzeveg and Meng 1998; Marivaux et al. 2002, 2004) who maintained the validity of Yuomyidae. Meanwhile, McKenna and Bell (1997) downgraded Yuomyidae and Cocomyidae to the subfamily level and included them under the Chapattimyidae along with Chapattimyinae and Baluchimyinae. It is indeed difficult to maintain the validity of two families based on insufficient diagnostic features and it appears more reasonable to separate them at the subfamily level as done by McKenna and Bell (1997). However, the same cannot necessarily be said about the downgrading of Cocomyidae by McKenna and Bell (1997), which are distinguished from chapattimyids and yuomyids by their non-molariform premolars. The presence of a combination of chapattimyid and yuomyid characters in the presently described teeth from Subathu supports the downgrading of yuomyids and therefore yuomyids are treated here as a subfamily under the Chapattimyidae. It further suggests that the chapattimyids and the yuomyids have evolved from a common ancestor and diverged later in the middle Eocene. More complete specimens are needed to assess the relationship between the Subathu rodents and other ctenodactyloids.

\section{4 ? Chapattimyids from Europe}

Peláez-Campomanes et al. (1989) described a few isolated rodent cheek teeth from the middle Eocene of Spain attributing them to cf. Chapattimyidae indet. and aff. Chapattimyidae indet. These were later attributed to a new genus and species, Zamoramys extraneus under an indeterminate family by Peláez-Campomanes and LópezMartínez (1996). Subsequent workers considered these teeth to be allied to theridomyids rather than to Asian ctenodactyloids (Vianey-Liaud et al. 1994; Escarguel 1999; Dawson 2003). More recently, however, Quer and Agustí (2010) included Zamoramys in a new family Remyidae along with Remys, Pairomys and a new genus Frontanyamys. Remyids differ from theridomyids mainly in having upper molars with very well-developed metaconule, from ischyromyids in having lophodont and hypsodont teeth and from chapattimyids in well-developed posterior arm of protoconid on lower molars, a metaconule nearly as large as metacone on upper molars and a paracone lingually positioned with respect to metacone on $\mathrm{P} 4$ (in Frontanyamys), and P4 much smaller than molars (in Zamoramys). It may be noted here that resemblance of remyids, particularly of Zamoramys and Frontanyamys and 
especially of their upper teeth with those of chapattimyids and yuomyids in features such as subequal protocone and hypocone (in Zamoramys), lingually shifted hypocone, protoloph and metaloph convergent towards the protocone and inflated metaconule, etc., is rather striking and should be probed further with more material to know their relationships with the Asian ctenodactyloids, particularly chapattimyids.

\subsection{Limited spread of ailuravines and dominance of chapattimyids on India}

The earliest rodents that lived on the Indian subcontinent were apparently the ailuravines (Ischyromyidae), which are presently known by a single taxon Meldimys musak from the early Eocene ( $54-53 \mathrm{Ma})$ of western peninsular India (Rana et al. 2008). Ailuravine assemblages are well known from the Eocene of Europe (Ypresian-Bartonian) and North America (Ypresian-Priabonian) (e.g., Michaux 1968; Korth 1988, 1994; Escarguel 1999). The lone ailuravine from India, Meldimys musak is somewhat more derived than the earliest Eocene European taxa, such as Euromys cardosoi and Euromys sp., which occur near the PaleoceneEocene $(\mathrm{P} / \mathrm{E})$ boundary and more primitive than the late-early Eocene taxa, E. inexpectatus and Ailuravus michauxi. Morphologically, it is more similar to European than to American lineages and evolutionary level of the Indian species appears to be close to those occurring in Europe around 52 Ma. The common occurrence of Meldimys in the early Eocene of India and Europe points to a faunal exchange between these two widely separated regions near the $\mathrm{P} / \mathrm{E}$ transition. Though it is unclear at this stage as to whether ailuravines originated in southern Asia and migrated to Europe or vice versa. The derived nature of $M$. musak compared to the more diverse earliest Eocene ailuravines from Europe (known by three genera and eight species) for now seems to favour a European origin for the subfamily.

Ailuravines survived in Europe until the latest middle Eocene (late Bartonian) and in North America throughout the Eocene (WasatchianChadronian), but they are yet to be found in the younger Eocene (Lutetian) faunas of the Indian subcontinent. Unfortunately, rodents in Vastan have so far been recovered only from a single level, therefore there is no way to know whether or not ailuravines survived beyond early Eocene even in the Vastan local fauna. Also it is not known whether ailuravines could ever spread to the sub-Himalayan region and lived alongside the chapattimyids and yuomyids at any point of time. In otherwise very rich and quite diverse
Vastan vertebrate fauna with plenty of predators, especially snakes, the presence of just one rodent species is rather surprising and may be an artefact.

The apparent lack of diversification of ailuravines in the Vastan fauna, where other small mammals such as bats and primates show rather high diversity, and their apparent absence in the successively younger rodent faunas of the subcontinent (e.g., Barbara Banda and Ganda Kas in Pakistan, and Subathu and Kalakot in India) seems to suggest that they may not have survived on the subcontinent beyond early Eocene and may have been replaced by the chapattimyids, which originated on the subcontinent and spread rather quickly in the central Asia, including Kazakhstan, China and Mongolia. Chapattimyids survived until the Miocene (Baluchimyinae, Flynn et al. 1986), though there is no record of chapattimyines beyond middle Eocene.

Morphologically, the ailuravines and chapattimyids are distinct and there appears to be no ancestor-descendant relationship between them. This would suggest that these two rodent groups originated independently at different points of time from different ancestors, but the question arises whether they originated on different continents or on the same continent. Additional material from the sub-Himalayan as well as western peninsular Indian localities is expected to throw light on this.

\subsection{Terrestrial faunal exchange between India and Europe near the $P / E$ transition}

The occurrence of a European ailuravine rodent genus, Meldimys in the early Eocene vertebrate fauna from Vastan (western peninsular India) was the first strong indication of a possible terrestrial faunal exchange between India and Eurasia close to the $\mathrm{P} / \mathrm{E}$ transition (Rana et al. 2008). Although initially considered rather tenuous, owing principally to the existence of Turgai Strait (=West Siberian Sea) between Europe and Asia, and the Tethys Sea between India and Asia, which would have been formidable physical barriers for any cross-infiltration of land vertebrates around the $\mathrm{P} / \mathrm{E}$, the evidence has since become stronger. Apart from the ailuravine rodents, there are now several other elements in the Vastan fauna, which also have European or North American affinities. These include diacodexeid artiodactyls, notharctid and omomyid primates, chiropterans (bats), esthonychine tillodonts, and also birds (Smith et al. 2007; Rana et al. 2008; Rose et al. 2009a, b, 2013; Kumar et al. 2010; Mayr et al. 2010). IndiaEurope faunal link also gets support from studies 
on dinoflagellate cysts by Iakovleva et al. (2001), which indicate lowering of sea level around the $\mathrm{P} / \mathrm{E}$, and on Eocene primate Teilhardina by Smith et al. (2006). Movement of fauna to and from India across the Tethys could have been facilitated by the presence of some hypothetical microcontinents and islands north of India as envisaged by Gaetani and Garzanti (1991) and Gingerich et al. (1997) or through potential land connections with AfroArabia during the northward drift (Gingerich et al. 1990; Chatterjee and Scotese 1999; Murphy et al. 2001). It may be mentioned here that Rose et al. (2014), while demonstrating that the mammalian group Perissodactyla originated in India opined that the stem taxa of perissodactyls could have entered India from Afro-Arabia possibly during the Paleocene.

Significantly, there is now substantial evidence of terrestrial faunal exchange between Asia and Europe also at the Cretaceous/Tertiary (K/T) transition - good $\sim 10$ Ma before ailuravines and others crossed-over. Adapisoriculid mammals (e.g., Deccanolestes) after their origin during the Maastrichtian on India quickly dispersed into Europe possibly via eastern Africa or directly across the Tethys into Europe and then to Africa (Boyer et al. 2010; Prasad et al. 2010; Smith et al. 2010; Goswami et al. 2011; De Bast et al. 2012). So if adapisoriculids could migrate to Europe from India around the $\mathrm{K} / \mathrm{T}$ boundary, similar dispersal may also have happened around the $\mathrm{P} / \mathrm{E}$ boundary. However, it remains to be seen whether $\mathrm{P} / \mathrm{E}$ and $\mathrm{K} / \mathrm{T}$ dispersals followed similar routes, and what were those routes?

The early Eocene Subathu horizons have so far yielded only rodents though there are definite indications of presence of other small mammal remains. It would be interesting to study their affinities and see if they are closer to European and American faunas or to the Asian faunas and also their relationship with the Vastan local fauna. The bulk screen-washing of the older Subathu red beds is likely to yield a more representative assemblage, including the small mammal groups such as primates, artiodactyls and chiropterans, etc., of the fauna that thrived in the sub-Himalayan region during the early Eocene.

\section{Summary and conclusions}

Chapattimyid rodents from the early Eocene horizons of the sub-Himalaya are represented by two new taxa, namely, Subathumys solanorius gen. et sp. nov. and Subathumys globulus gen. et sp. nov., and three others, including, Birbalomys cf. sondaari, Birbalomys sp. and cf. Chapattimys sp. All are found on/identified by upper molars, and the lower cheek teeth have been described provisionally as indeterminate chapattimyids pending definitive taxonomic assignments when additional material is forthcoming. The moderate diversity of the early Eocene Subathu rodents indicates their early radiation in this fauna.

The co-occurrence of typical chapattimyid and yuomyid characters in the presently described cheek teeth suggests that the two rodent groups may have evolved from a common ancestor and diverged later in the middle Eocene. It also supports the downgrading of Yuomyidae to a subfamily level and bringing it under the Chapattimyidae by McKenna and Bell (1997). More complete specimens are needed to assess the relationship between the Subathu rodents and other ctenodactyloids.

The early Eocene chapattimyid-yielding section at Subathu is chronologically intermediate between the Vastan mine section (Gujarat) of peninsular India and the Kalakot-Metka and Ganda KasChorlakki sections of northern India and Pakistan, respectively. It is probably also younger than the Barbara Banda section of Pakistan. Chronologically, it is closest to the early middle Eocene rodent-yielding sections of northern India and Pakistan as also supported by the close similarity of certain early Eocene taxa with those from the middle Eocene.

Contrary to the earlier belief based on data from Kalakot-Metka and Subathu in India and Ganda Kas-Chorlakki in Pakistan (Hussain et al. 1978; Kumar et al. 1997a, b), the chapattimyids originated in the early Eocene on the subcontinent rather than in middle Eocene and were probably the dominant rodent group during early and middle Eocene, which did not allow the migrant ailuravines to flourish beyond early Eocene. However, the oldest known fossil rodents from India belonged to the cosmopolitan family Ischyromyidae rather than to endemic Chapattimyidae, and it is not clear if the two distinct groups ever lived together.

Ailuravines appear to have failed to disperse into the sub-Himalayan region, even though other groups such as diacodexeids, whose oldest Indian record is also from the peninsular India could do so and are also known from the Lutetian horizons in the sub-Himalaya.

An extensive and systematic collecting in the older red beds of the Subathu Formation can be expected to yield a more representative assemblage, including other small mammal groups such as primates, artiodactyls and chiropterans, etc., of the fauna that thrived in the sub-Himalayan region during the early Eocene and help understand their relationship and palaeobiogeography vis-à-vis Eocene terrestrial faunas from peninsular India, Pakistan, Europe and North America. 


\section{Acknowledgements}

Authors are thankful to Ashok Sahni (Panjab University, Chandigarh), J-L Hartenberger, M Vianey-Liaud and Laurent Marivaux (University of Montpellier) and Giles Escarguel (University of Lyone 1) for commenting on the fossil material. They also thank the two anonymous reviewers for their critical comments and useful suggestions which improved the paper. Director, Wadia Institute of Himalayan Geology (WIHG), Dehradun provided various facilities for this research. SEM micrographs were made at the WIHG.

\section{References}

Averianov A 1996 Early Eocene Rodentia of Kyrgyzstan; Bull. Mus. Natl. Hist. Nat. Paris Ser. 4 18C(4) 629-662.

Bajpai S and Gingerich P D 1998 A new Eocene archaeocete (Mammalia, Cetacea) from India and the time of origin of whales; Proc. Nat. Acad. Sci. 95 15,464-15,468.

Bajpai S, Kapur V V, Das D P, Tiwari B N, Sarvanan N and Sharma R 2005 Early Eocene land mammals from Vastan lignite mine, District Surat (Gujarat), western India; J. Palaeontol. Soc. India 50 101-113.

Bajpai S, Das D P, Kapur V V, Tiwari B N and Srivastava S S 2007 Early Eocene rodents (Mammalia) from Vastan lignite mine, Gujarat, western India; Gond. Geol. Mag. 22 91-95.

Bowdich T E 1821 An analysis of the natural classification of mammals for the use of students and travellers; J Smith, Paris, 115p.

Boyer D M, Prasad G V R, Krause D W, Godinot M, Goswami A, Verma O and Flynn J J 2010 New postcrania of Deccanolestes from the late Cretaceous of India and their bearing on the evolutionary and biogeographic history of euarchontan mammals; Naturwissenschaften $\mathbf{9 7}$ $365-377$.

Chatterjee S and Scotese C R 1999 The breakup of Gondwana and the evolution and biogeography of the Indian Plate; Proc. Indian Nat. Sci. Acad. 65A 397-425.

Dashzeveg D and Meng J 1998 New Eocene ctenodactyloid rodents from the Eastern Gobi Desert of Mongolia and a phylogenetic analysis of ctenodactyloids based on dental features; Amer. Mus. Novitates 3246 1-20.

Dawson M R 2003 Paleogene rodents of Eurasia; In: Distribution and migration of tertiary mammals in Eurasia; A volume in honour of Hans de Bruijn (eds) Reumer J W F and Wessels W, Deinsea 10 97-126.

Dawson M R and Beard C K 1996 New late Paleocene rodents (Mammalia) from Big Multi Quarry, Washakie Basin, Wyoming; Palaeovertebrata 25 301-321.

Dawson M R, Li C K and Qi T 1984 Eocene ctenodactyloid rodents (Mammalia) of eastern and central Asia; In: Papers in Vertebrate Paleontology honoring Robert Warren Wilson (ed.) Mengel R M, Carnegie Museum of Natural History, Pittsburgh, pp. 138-150.

De Bast E, Bernard S and Smith T 2012 Diversity of the adapisoriculid mammals from the early Palaeocene of Hainin, Belgium; Acta Palaeontol. Pol. 57 35-52.

De Bruijn H, Hussain S T and Leinders J M 1982 On some early Eocene rodent remains from Barbara Banda, Kohat, Pakistan and the early history of the Order Rodentia; Proc. Konink. Neder. Akad. van Wetensch. Ser. B $\mathbf{8 5}$ 249-258.
Escarguel G 1999 Les rongeurs de l'Eocène inférieur et moyen d'Europe occidentale; Systématique, phylogénie, biochronologie et paleobiogéographie des niveaux repères MP 7 B MP 14; Palaeovertebrata 28 1-351.

Flynn L J, Jacobs L L and Cheema I U 1986 Baluchimyinae, a new ctenodactyloid rodent subfamily from the Miocene of Baluchistan; Amer. Mus. Novitates 2841 1-58.

Gaetani M and Garzanti E 1991 Multicyclic history of the northern India continental margin (northwestern Himalaya); Amer. Assoc. Petrol. Geol. Bull. 75(9) 14271446.

Garg R, Khowaja-Ateequzzaman, Prasad V, Tripathi S K M, Singh I B, Jauhri A K and Bajpai S 2008 Age-diagnostic dinoflagellate cysts from lignite-bearing sediments of the Vastan lignite mine, Surat District, Gujarat, western India; J. Palaeontol. Soc. India 53 99-105.

Gingerich P D, Wells N A, Russell D E and Shah S M I 1983 Origin of whales in epicontinental remnant seas: New evidence from the early Eocene of Pakistan; Science 220 403-406.

Gingerich P D, Russell D E and Wells N A 1990 Astragalus of Anthracobune (Mammalia, Proboscidea) from the early-middle Eocene of Kashmir; Contrib. Mus. Paleontol., Univ. Michigan 28 71-77.

Gingerich P D, Abbas S G and Arif M 1997 Early Eocene Quettacyon parachai (Condylarthra) from the Ghazij Formation of Baluchistan (Pakistan): Oldest Cenozoic land mammal from South Asia; J. Vert. Paleontol. 17(4) 629-637.

Goswami A, Prasad G V R, Upchurch P, Boyer D M, Seiffert E R, Verma O, Gheerbrant E and Flynn J J 2011 A radiation of arboreal basal eutherian mammals beginning in the late Cretaceous of India; Proc. Nat. Acad. Sci. 108 16,333-16,338.

Hartenberger J L 1982 A review of the Eocene rodents of Pakistan; Contrib. Mus. Paleontol., Univ. Michigan 26 19-35.

Hussain S T, De Bruijn H and Leinders J M 1978 Middle Eocene rodents from the Kala Chitta Range (Punjab, Pakistan); Proc. Konink. Nederl. Akad. Wetensch. Ser. B 81 74-112.

Iakovleva A I, Brinkhuis H and Cavagnetto C 2001 Late Palaeocene-Early Eocene dinoflagellate cysts from the Turgay Strait, Kazakhstan: Correlations across ancient seaways; Palaeogeogr. Palaeoclimatol. Palaeoecol. 172 $243-268$.

Khan I H and Clyde W C 2013 Lower Paleogene tectonostratigraphy of Balochistan: Evidence for timetransgressive Late Paleocene-Early Eocene uplift; Geosciences 3 466-501.

Korth W W 1988 The rodent Mytonomys from the Uintan and Duchesnean (Eocene) of Utah, and the content of Ailuravinae (Ischyromyidae, Rodentia); J. Vert. Paleontol. 8 290-294.

Korth W W 1994 The tertiary record of rodents in North America; In: Topics in Geobiology (eds) Stehli F G and Jones D S, Plenum Press Publishers, 12 1-319.

Kumar K 1989 A report on the occurrence of microvertebrates in the Subathu Formation (Eocene), near Nilkanth, Garhwal Himalaya, Uttar Pradesh; Curr. Sci. 58 743746.

Kumar K 1991 Anthracobune aijiensis nov. sp. (Mammalia: Proboscidea) from the Subathu Formation, Eocene from northwest Himalaya, India; Geobios. 24 221-239.

Kumar K 1992 Paratritemnodon indicus (Creodonta: Mammalia) from the early Middle Eocene Subathu Formation, northwest Himalaya, India and the Kalakot mammalian community structure; Palaontol. Zeitschrift 66 415-431. 
Kumar K 2000 Correlation of continental Eocene vertebrate localities of the Indian subcontinent; Him. Geol. 21 63-85.

Kumar K and Jolly A 1986 Earliest artiodactyl (Diacodexis, Dichobunidae: Mammalia) from the Eocene of Kalakot, northwestern Himalaya, India; Indian Soc. Geosci. Bull. $220-30$.

Kumar K and Loyal R S 1987 Eocene ichthyofauna from the Subathu Formation, northwestern Himalaya, India; J. Palaeontol. Soc. India 32 60-84.

Kumar K and Loyal R S 2006 Excursion guide on sub-Himalayan Palaeogene succession of Shimla Hills (Subathu-Dagshai-Kasauli formations in Stratotype Area, Solan District, Himachal Pradesh); Unpublished, Wadia Institute of Himalayan Geology, Dehradun, 61p.

Kumar K and Sahni A 1985 Eocene mammals from the Upper Subathu Group, Kashmir Himalaya, India; J. Vert. Paleontol. 5 153-168.

Kumar K, Loyal R S and Srivastava R 1997a Eocene rodents from new localities in Himachal Pradesh, northwest Himalaya, India: Biochronologic implications; J. Geol. Soc. India 50 461-474.

Kumar K, Srivastava R and Sahni A 1997b Middle Eocene rodents from the Subathu Group, northwest Himalaya; Palaeovertebrata 26 83-128.

Kumar K, Rose K D, Rana R S, Singh L, Thierry S and Sahni A 2010 Early Eocene artiodactyls (Mammalia) from western India; J. Vert. Paleontol. 30 1245-1274.

Leinders J J M, Arif M, De Bruijn H, Hussain S T and Wessels W 1999 Tertiary continental deposits of northwestern Pakistan and remarks on the collision between the Indian and Asian plates; Deinsea 7 199-213.

Li C K, Wilson R W, Dawson M R and Krishtalka L 1987 The origin of rodents and lagomorphs; In: Current Mammalogy 1 (ed.) Genoways H H, Plenum Press, New York, pp. $97-108$.

Linnaeus (Linné) C 1758 Systema naturae per regna tria naturae, secundum classes, ordines, genera, species, cum characteribus, differentiis, synonymis, locis; Vol 1: Regnum animale. Editio decimal, reformata. Stockholm: Laurentii Salvii. [Facsimile reprinted in 1956 by the British Museum (Natural History).]

Marivaux L, Vianey-Liaud M and Jaeger J J 2004 High level phylogeny of early tertiary rodents: Dental evidence; Zool. J. Linn. Soc. 142 105-134.

Marivaux L, Wecomme J-L, Vianey-Liaud M and Jaeger J J 2002 The role of Asia in the origin and diversification of hystricognathous rodents; Zoologica Scripta 31 225-239.

Mathur N S and Juyal K P 2000 Atlas of early Palaeogene invertebrate fossils of the Himalayan foothills belt; Wadia Institute of Himalayan Geology, Monograph series, Bishen Singh Mahendra Pal Singh, Dehradun, 257p.

Mayr G, Rana R S, Rose K D, Sahni A, Kumar K, Singh L and Smith T 2010 Quercypsitta-like birds from the early Eocene of India (Aves, ?Psittaciformes); J. Vert. Paleontol. 30 467-478.

McKenna M C and Bell S K (eds) 1997 Classification of mammals above the species level; Columbia University Press, New York.

Meng J and Li C K 2010 New rodents from the earliest Eocene of Nei Mongol, China; Vertebrata PalAsiatica 48 390-401.

Michaux J 1968 Les Paramyidae (Rodentia) de L'Eocène inférieur du Bassin de Paris; Palaeovertebrata 1(4) 135-193.

Murphy W J, Eizirik E, Johnson W E, Zhang W P, Ryder O Y and O'Brien S J 2001 Molecular phylogenetics and the origins of placental mammals; Nature 409 614-618.

Nanda A C and Kumar K 1999 Excursion guide on the Himalayan Foreland Basin (Jammu-Kalakot-Udhampur sector); Wadia Institute of Himalayan Geology Spec. Publ. 2 1-89.

Peláez-Campomanes P and López-Martínez N 1996 Strange Eocene rodents from Spain; Palaeovertebrata 25 323-338.

Peláez-Campomanes P, De la Peňa A and López Martínez N 1989 Primeras faunas de micromammíferos del Paleógeno de la Cuenca del Duero; Studia Geologica Salmanticensia 5 135-157.

Pivnik D A and Wells N A 1996 The transition from Tethys to the Himalaya as recorded in northwest Pakistan; Geol. Soc. Am. Bull. 108 1295-1313.

Prasad G V R, Verma O, Gheerbrant E, Goswami A, Khosla A, Parmar V and Sahni A 2010 First mammal evidence from the late Cretaceous of India for biotic dispersal between India and Africa at the $\mathrm{KT}$ transition; C.R. Palevol. 9 63-71.

Punekar J and Saraswati P K 2010 Age of the Vastan lignite in context of some oldest Cenozoic fossil mammals from India; J. Geol. Soc. India 76 63-68.

Quer R and Agustí J 2010 A new genus of rodents (Remyidae, Mammalia) from the Iberian Eocene; Palaeontology $5353-58$.

Rana R S, Kumar K and Singh H 2004 Vertebrate fauna from the subsurface Cambay Shale (lower Eocene), Vastan lignite mine, Gujarat, India; Curr. Sci. 87 17261733.

Rana R S, Kumar K, Escarguel G, Sahni A, Rose K D, Smith T, Singh H and Singh L 2008 An ailuravine rodent from the lower Eocene Cambay Formation at Vastan, western India, and its palaeobiogeographic implications; Acta Palaeontol. Polonica 53 1-14.

Ranga Rao A 1971 Discovery of bone and plant beds at the top of Subathu and its bearing on the SubathuMurree/Dharamsala/Dagshai contact in the Himalayan foothills; Bull. ONGC $\mathbf{8} 43-46$.

Ranga Rao A and Mishra V N 1981 On the new Eocene mammal localities in the Himalayan foothills; Him. Geol. $11422-428$.

Rose K D 1981 The Clarkforkian land mammal age and mammalian faunal composition across the PaleoceneEocene boundary; Papers on Paleontol., Mus. Paleontol., Univ. Michigan 26 1-197.

Rose K D, Rana R S, Sahni A, Kumar K, Missiaen P, Singh L and Smith T 2009a Early Eocene primates from Gujarat, India; J. Human Evol. 56 366-404.

Rose K D, Rana R S, Sahni A, Kumar K, Singh L and Smith T 2009b First tillodont mammal from India: Additional evidence for an early Eocene faunal connection between Europe and India? Acta Palaeontol. Polonica 54 351-355.

Rose K D, Kumar K, Rana R S, Sahni A and Smith T 2013 New hypsodont tillodont (Mammalia, Tillodontia) from the early Eocene of India; J. Paleontol. 87 842-853.

Rose K D, Holbrook L T, Rana R S, Kumar K, Jones K E, Ahrens H E, Missiaen P, Sahni A and Smith T 2014 Early Eocene fossils suggest that the mammalian order Perissodactyla originated in India; Nat. Commun. 5 5570, doi: 10.1038/ncomms6570.

Sahni A and Khare S K 1973 Additional Eocene mammals from the Subathu Formation of Jammu and Kashmir; J. Palaeontol. Soc. India 17 31-49.

Sahni A and Kumar K 1980 Lower Eocene Sirenia, Ishatherium subathuensis, gen. et sp. nov. from the type area, Subathu Formation, Subathu, Simla Himalayas, H.P.; J. Palaeontol. Soc. India 23\&24 132-135.

Sahni A and Srivastava V C 1976 Eocene rodents and associated reptiles from the Subathu Formation of northwestern India; J. Paleontol. 50 922-928.

Sahni A, Bhatia S B, Hartenberger J L, Jaeger J J, Kumar K, Sudre J and Vianey-Liaud M 1980a Vertebrates from 
the Subathu Formation and comments on the biogeography of Indian subcontinent during the early Palaeogene; Bull. Geol. Soc. France 23 689-695.

Sahni A, Kumar K and Tiwari B N 1980b Lower Eocene marine mammal (Sirenia) from Dharampur, Simla Himalaya, H.P.; Curr. Sci. 49 270-271.

Sahni A, Saraswati P K, Rana R S, Kumar K, Singh H, Alimohammadian H, Sahni N, Rose K D, Singh L and Smith T 2006 Temporal constraints and depositional palaeoenvironments of the Vastan lignite sequence, Gujarat: Analogy for the Cambay Shale hydrocarbon source rock; Indian J. Petrol. Geol. 15 1-20.

Sheveyreva N S 1972 New rodents from the Paleogene of Mongolia and Kazakhstan; Paleontologicheskii Zhurnal $\mathbf{3}$ 134-145.

Sheveyreva N S 1976 Paleogene rodents of Asia (families Paramyidae, Sciuravidae, Ischyromyidae, Cylindrodontidae); Trudy Paleontologischeskogo Instituta Academii Nauk USSR 158 1-116.

Singh P 1980 The Subathu Group of India; Professional Paper 1, Nav Jyoti Scientific Publications, Lucknow, pp. 1-92.

Smith T, Rose K D and Gingerich P D 2006 Rapid AsiaEurope-North America geographic dispersal of earliest Eocene primate Teilhardina during the Paleocene-Eocene thermal maximum; Proc. Nat. Acad. Sci. 103 11,22311,227 .

Smith T, Rana R S, Missiaen P, Rose K D, Sahni A, Singh H and Singh L 2007 High bat diversity in the early Eocene of India; Naturwissenschaften 94 1003-1009.
Smith T, De Bast E and Bernard S 2010 Euarchontan affinity of Paleocene Afro-European adapisoriculid mammals and their origin in the late Cretaceous deccan traps of India; Naturwissenschaften $97417-$ 422.

Srivastava R and Kumar K 1996 Taphonomy and paleoenvironment of the middle Eocene rodent localities of northwestern Himalaya, India; Palaeogeogr. Palaeoclimatol. Palaeoecol. $122 \quad 185-$ 211.

Thewissen J G M, Russell D E, Gingerich P D and Hussain S T 1983 A new dichobunid artiodactyl (Mammalia) from the Eocene of north-west Pakistan. Dentition and classification; Proc. Konink. Nederl. Akad. Wetensch. Ser. B 86 153-180.

Thewissen J G M, Williams E M and Hussain S T 2001 Eocene mammal faunas from northern Indo-Pakistan; J. Vert. Paleontol. 21 347-366.

Tullberg T 1899 Ueber das Systern der Nagethiere: eine phylegenetische Studie; Akademischen Buchdruckerei, Upsala, pp. 1-514.

Vianey-Liaud M, Schmidt-Kittler N and PeláezCampomanes P 1994 Pairomys et Ectropomys: la fin d'une ambiguite; mise au point sur les Oltinomyinae et Remyinae (Rodentia, Theridomyidae); Palaeovertebrata 23(1-4) 119-152.

Wang B 1994 The Ctenodactyloidea of Asia; In: Rodent and Lagomorph families of Asian origin and diversification (eds) Tomida Y, Li C and Setoguchi T, Natl. Sci. Mus. Monogr. Tokyo 8 35-47. 